\title{
A review on design and testing methodologies of modern freight train draft gear system
}

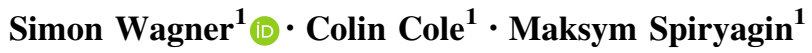

Received: 8 December 2020/Revised: 26 April 2021/Accepted: 27 April 2021/Published online: 7 June 2021

(C) The Author(s) 2021

\begin{abstract}
Rolling stock connection systems are key to running longer and heavier trains as they provide both the connections of vehicles and the damping, providing the longitudinal suspension of the train. This paper focuses on the evolution of both connection and stiffness damping systems. Focus is on freight rolling stock, but passenger draw gears are also examined. It was found that connection systems have evolved from the buff and chain system used in the pioneer railways of the 1800 s to the modern auto-coupler connection systems that are in-service worldwide today. Refined versions of the buff and chain coupling are, however, still in use in the EU, UK, South America and India. A wide range of auto-coupler systems are currently utilised, but the AAR coupler (Janney coupler) remains the most popular. A further variation that persists is the SA3 coupler (improved Wilson coupler) which is an alternative auto-coupler design used mainly throughout the former Soviet Union. Restricting the review to auto-coupler systems allowed the paper to focus on draft gears which revealed polymer, polymer-friction, steel spring-friction, hydraulic draft gears and sliding sill cushioning systems. Along with the single compressive draft gear units balanced and floating plate configurations are also presented. Typical draft gear acceptance standards are presented along with modelling that was included to aid in presentation of the functional characteristics of draft gears.
\end{abstract}

Keywords Railway · Draft gear · Coupler · Rolling stock · Freight train

Simon Wagner

s.wagner@cqu.edu.au

1 Centre for Railway Engineering, Central Queensland University, Rockhampton, Australia

\section{Introduction}

The push to increase the throughput of a given railway system has been an objective for railways since the pioneer railway days. As the demand on railway systems has increased, railways have had to innovate to achieve higher throughputs. Increased throughputs of railway systems have been achieved by

(1) Increased train payload

(a) Increasing train length

(b) Increased wagon payload

(c) Improved driver actions

(2) Reductions in cycle time

(a) Increased train speed

(b) Increased loading rates

(c) Increased unloading rates

(3) Increasing the number of trains on a railway system.

Operating very long and heavy trains requires considerable driver experience especially on steep undulating grades. An experienced driver can reduce in-train forces and shorten cycle times through smooth and optimised driver actions. A very talented and experienced driver can put the train in steady and stable state. Driving trains is a unique skillset which has a direct impact on railway operating costs, maintenance and service life.

Increases of train payload also require improvements in rolling stock connection systems. Rolling stock connections systems are key to running longer and heavier trains as they provide both connections of the vehicles and damping (of buffering) between them, in essence a longitudinal suspension system. 
Rolling stock connection systems allow for the formation of a train from individual railway vehicles. These connection systems are made up of several components and the assembly is often collectively referred to as a 'Draw Gear' and permits forces to be transmitted from vehicle to vehicle which allows for towing and braking. The functions of rolling stock connection systems are as follows:

(1) Provide quick and safe connection/disconnection of rolling stock.

(2) Transmit the towing and braking forces along the train.

(3) Absorb shocks, impacts and collisions. The wagon connection system is required to be stiff enough to transmit steady state forces while being soft enough to absorb shocks and impacts, including crash and derailment conditions.

(4) Incorporate coupler slack to ensure that the locomotives do not have to overcome the static rolling resistance of the whole train in a single occurrence.

(5) Allow for train partings by sacrificial component failure to reduce rolling stock being damaged during high force or derailment events. This is similar to a fuse in an electrical system.

Rolling stock connections in the early 1800 s consisted of simple buffers and chain couplings which had limited capacity, were unsafe and had considerable slack action $[1,2]$. These systems have evolved considerably since that time. Traditionally the functions of connection and longitudinal damping are achieved by separate components in the rolling stock connection system. Connections are provided by various forms of couplings: draw hooks, couplers and drawbars. Damping is provided by draft gears, buffers and cushioning systems. Over the years there have been many different designs of 'Draw Gear' systems developed for different applications. There has also been continuous improvement and optimisation.

This paper aims to provide an overview and investigation of connection systems and draft gear design. This includes a brief history of wagon connection systems in Sect. 2, followed by a review of the different draft gear and connection systems in modern freight trains in Sect. 3. Section 3 also includes the application categories of different draft gears. Section 4 reviews international acceptance standards which have shaped the products available on the market. Sections 5-10 review the performance and characteristics of each type of draft gear. Section 11 discusses draft gear modelling. The discussion and conclusion are presented in Sects. 12 and 13.

\section{Wagon connection systems: a historic perspective}

The very first documented wagonway mine cart was in 1556 by Georgius Agricola in his German book De Re Metallica [3]. The railway wheels were wooden unflanged wheels running on wooden logs [3]. A vertical pin was used as a wagon connection system [3]. The next known wagonway is the Wollaton Wagonway which was built in England around October 1604 [4]. It consisted of horse drawn wagons on wooden rails which ran from Strelley to Wollaton and was used to carry coal [4]. The type of connection system is not documented, but it is assumed to be a dual buffer and chain connection due to the dual hooks on the wagons. It is assumed that the buffers where the wooden blocks with a chain each side of the wagon.

Horse drawn railways were used in funiculars and coal mines as early as early 16th century [5]. Britain established the first locomotive powered railway in 27 September 1825; it was powered by Stephenson's Locomotion No. 1. Stephenson's Locomotion No. 1 was a steam locomotive with 2 cylinders with a maximum speed of $24 \mathrm{~km} / \mathrm{h}$ and $8.5 \mathrm{kN}$ of tractive effort. Stephenson's Locomotion No. 1 gave birth to the railways of the world and the first industrial revolution.

The invention of the locomotive powered railroad allowed the haulage of passengers and freight on a greater scale. It boosted the productivity of railway lines and started the rapid growth of locomotive powered railroads throughout the world. Railroads were rapidly established in Europe and America for passenger and freight services. African countries established railroads later than the rest of the world. Table 1 shows the first railway established in each continent.

Table 2 shows a history of American heavy haul wagon connection systems. Early damping designs sought to use friction to provide the energy dissipation element. According to $\mathrm{Wu}$ et al. [6], the first patent for a friction draft gear was in 1888 by George Westinghouse. However, the introduction into service of this draft gear did not begin until 1896 [6]. A popular connection system used is the

Table 1 First established year per continent

\begin{tabular}{ll}
\hline Continent & Year of first railway \\
\hline Africa & 1854 \\
Asia & 1838 \\
Europe & 1825 \\
Middle East & 1887 \\
Oceania & 1831 \\
America & 1827 \\
\hline
\end{tabular}


Table 2 History of American heavy haul wagon connection systems

\begin{tabular}{|c|c|c|}
\hline $\begin{array}{l}\text { In-service } \\
\text { year }\end{array}$ & Connection & Overview \\
\hline $\begin{array}{l}\text { Early } \\
\quad 1800 s\end{array}$ & $\begin{array}{c}\text { Buffer and chain couplings } \\
{[1,10] . \text { Refer to Fig. } 1}\end{array}$ & $\begin{array}{l}\text { High levels of slack action were present } \\
\text { Screw tighteners added later to reduce slack [10] } \\
\text { Dangerous to crew } \\
\text { Longer trains introduced higher forces than the buffer and chain coupler could accommodate } \\
\text { Buffers consisted of wood, rubber blocks or springs [10] }\end{array}$ \\
\hline Mid 1800s & $\begin{array}{l}\text { Link and pin coupler }[1,2] \text {. Refer } \\
\text { to Fig. } 2\end{array}$ & $\begin{array}{l}\text { High levels of slack action were present } \\
\text { There was no standard design } \\
\text { Dangerous to crew } \\
\text { The links and pins were often stolen } \\
\text { Longer trains introduced higher forces than the buffer and chain coupler could accommodate }\end{array}$ \\
\hline 1866-1893 & Miller hook and platform $[1,11]$ & $\begin{array}{l}\text { The Miller hook and platform replaced the link and pin coupler } \\
\text { First hook and knuckle style couplers used in railways } \\
\text { The Miller Hook and Platform was later replaced by the Janney coupler }\end{array}$ \\
\hline $\begin{array}{l}1893 \\
\text { onwards }\end{array}$ & $\begin{array}{l}\text { Janney coupler }[1,2,7] \text {. Refer to } \\
\text { Fig. } 3\end{array}$ & $\begin{array}{l}\text { Improved safety } \\
\text { In } 1893 \text { the Unites States Congress passed the Safety Appliance Act which mandated the } \\
\text { Janney coupler throughout the United States [2]. As shown in Fig. } 4 \text { this resulted in a } \\
\text { significant reduction in the number of injuries and deaths per trainmen employed from } \\
\text { coupling and uncoupling cars } \\
\text { The Janney coupler is currently used in the United States, Canada, Mexico, Japan, Taiwan, } \\
\text { Australia, New Zealand, South Africa, Saudi Arabia, Cuba, Chile, Brazil, China and } \\
\text { elsewhere }\end{array}$ \\
\hline
\end{tabular}

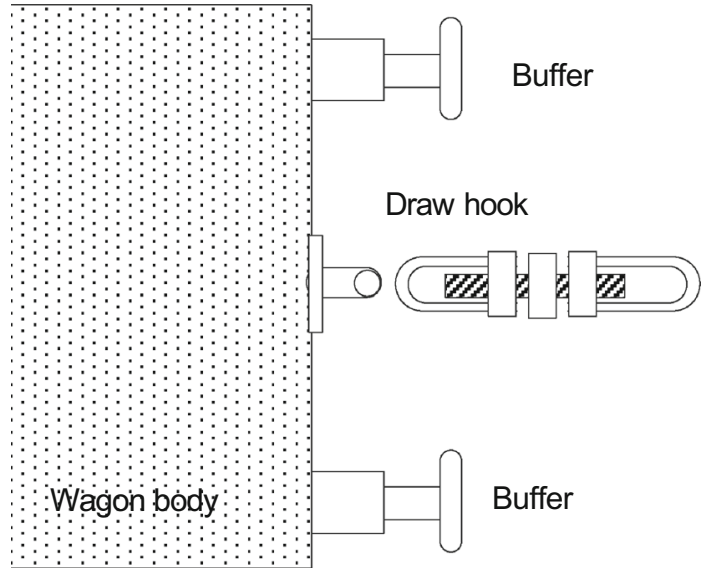

Fig. 1 Buff and chain coupler

Association of American Railroads (AAR) coupler or Janney coupler which was first patented in 1873 under patent number 183,405 [7]. The basic concept has stayed the same $[8,9]$ since it was first invented. It provides quick and safe connection/disconnection, incorporates coupler slack, transmits towing and braking forces and allows train partings in the event of high in-train forces.

The history of connection systems has been provided for the United States of America only. Undertaking a global

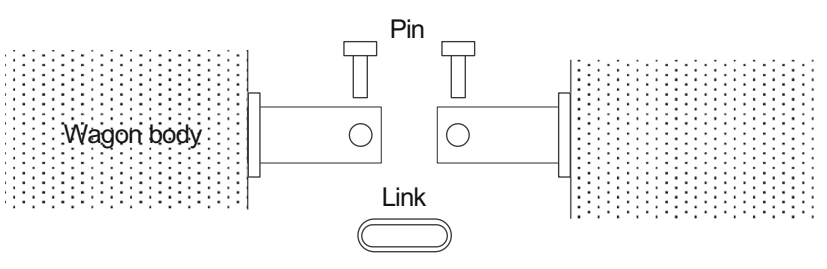

Fig. 2 Link and pin coupler

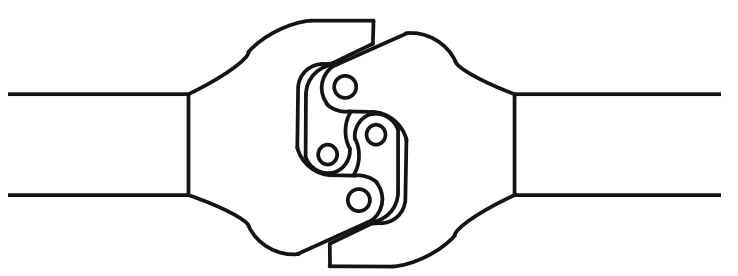

Fig. 3 Janney coupler

investigation into the history of connections systems would be highly complex with large amounts of information unavailable.

Buff and chain couplings have remained the standard in the European Union and the UK since the pioneer railway days [12]. A modern version of buff and chain couplings replaces the chain with a turnbuckle screw which slightly 


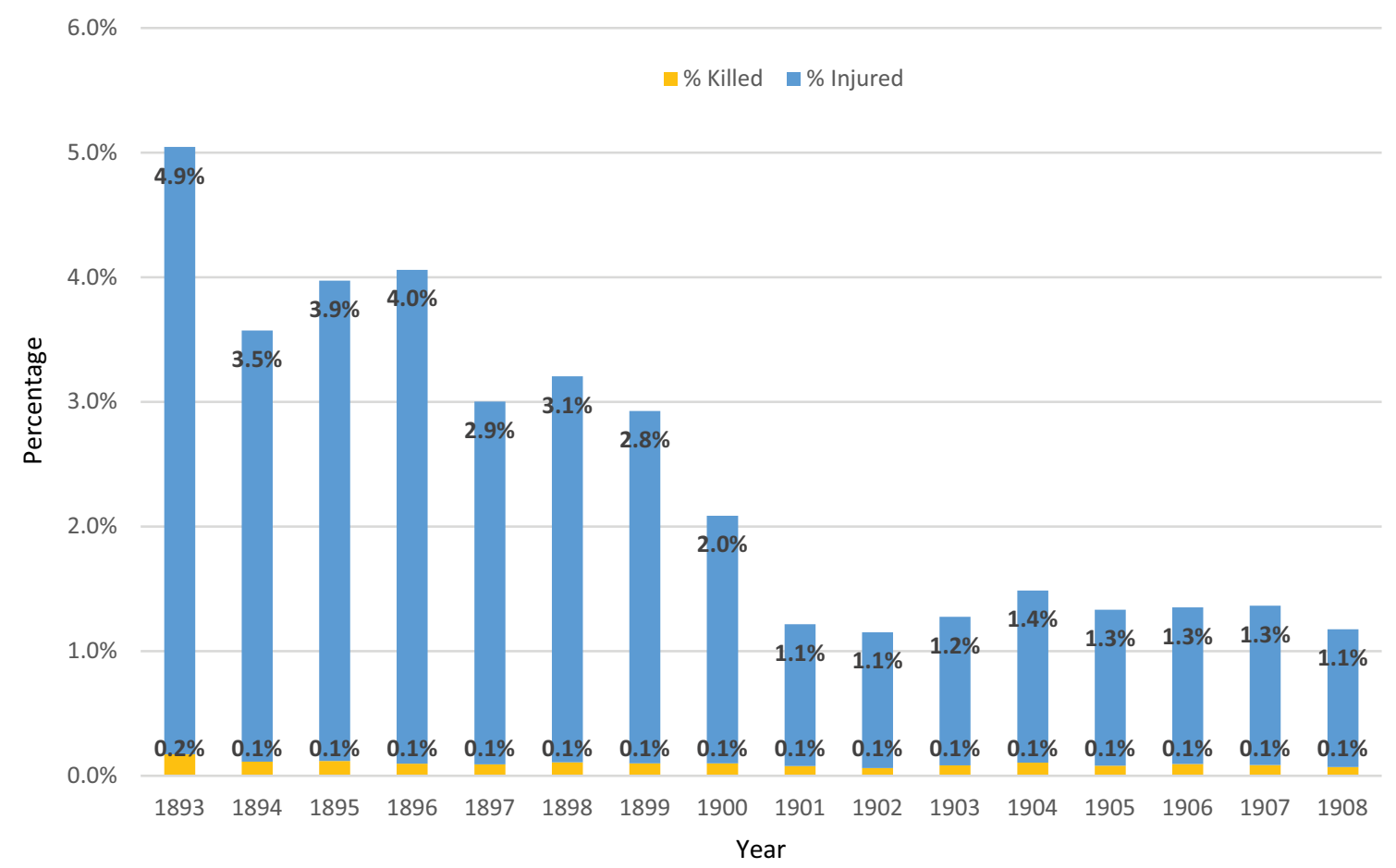

Fig. 4 Railway incidents per number of trainmen employed from coupling and uncoupling cars [2]

Table 3 Coupling system per country [12]

\begin{tabular}{ll}
\hline Continent & Connection system \\
\hline Africa & A wide variety of coupler systems are used throughout Africa including AAR couplers, buff and chain couplers, CBC couplers, \\
SA3 couplers and even link and pin couplers & AAR couplers are widespread on modern freight rolling stock including China, Hong Kong, India, Japan, North Korean, South \\
Asia & Korea, Thailand and Vietnam \\
North & AAR coupler is used for freight rolling stock in Canada, Mexico and the United States \\
America & \\
$\begin{array}{l}\text { Oceania } \\
\begin{array}{c}\text { South } \\
\text { America }\end{array}\end{array}$ & AAR couplers are used throughout Australia and New Zealand on modern freight rolling stock \\
\end{tabular}

compresses the buffers. The pioneer railways of the former Soviet Union also used the buff and chain coupler. In 1957 the former Soviet Union converted to the SA3 coupler which still remains today [13]. The SA3 coupler is an improved version of the Wilson Coupler.

AAR and buff and chain are widespread throughout the world and are the most common connect system used for modern freight rolling stock. Table 3 shows each continent and a brief outline of the connection systems used. For more information refer to [12]. This section has been provided as a brief overview. A full review of every country and a detailed history is outside the scope of this document.

\section{Overview of wagon connections in modern freight trains}

Different connection systems were found to be more suitable and/or cost effective for different train applications such as light freight, intermodal freight, heavy haul freight and passenger services. The connection systems used throughout the world on different rail networks varies considerably, as each railway network has its own requirements, history, standards and practices.

In some instances, buffer and chain couplers are still used today, particularly in the EU, UK and South America. This arrangement includes having buffers on either side of the wagon or a single buffer in the centre [10]. The 5th 
Table 4 Train applications-draft gears

\begin{tabular}{|c|c|c|c|c|c|}
\hline \multirow[t]{3}{*}{ Train application } & \multicolumn{4}{|c|}{ Freight } & \multirow{3}{*}{$\begin{array}{l}\text { Hauled } \\
\text { passenger cars }\end{array}$} \\
\hline & \multirow[t]{2}{*}{ Light } & \multirow[t]{2}{*}{ Intermodal } & \multicolumn{2}{|c|}{ Heavy haul } & \\
\hline & & & Coal & $\begin{array}{l}\text { Iron } \\
\text { ore }\end{array}$ & \\
\hline Steel spring and friction damper systems & $\times$ & $\boldsymbol{V}$ & $\checkmark$ & $\checkmark$ & $\times$ \\
\hline Polymer spring and friction damper systems & $\boldsymbol{V}$ & $\boldsymbol{V}$ & $\checkmark$ & $\checkmark$ & $\times$ \\
\hline Polymer spring systems (short packs) & $\times$ & $\times$ & $\checkmark$ & $x$ & $\times$ \\
\hline Polymer spring systems (standard) & $\boldsymbol{\sim}$ & $\times$ & $x$ & $\times$ & $\boldsymbol{\sim}$ \\
\hline \multicolumn{6}{|l|}{ Other draft gear types } \\
\hline $\begin{array}{l}\text { Double buff packs consisting of a two damper system (either steel or polymer spring and } \\
\text { friction damper systems) }\end{array}$ & & $\checkmark$ & & & \\
\hline Hydraulic systems & & $\checkmark$ & & & \\
\hline Balanced polymer systems & $\checkmark$ & & & & $\boldsymbol{\sim}$ \\
\hline Floating plate polymer systems & $\boldsymbol{V}$ & & & & $\boldsymbol{V}$ \\
\hline Polymer spring systems (long) & & Proposed & & & \\
\hline
\end{tabular}

Symbols $\boldsymbol{V}$ and $\times$ indicate that the damping system is and is not used in the application, respectively

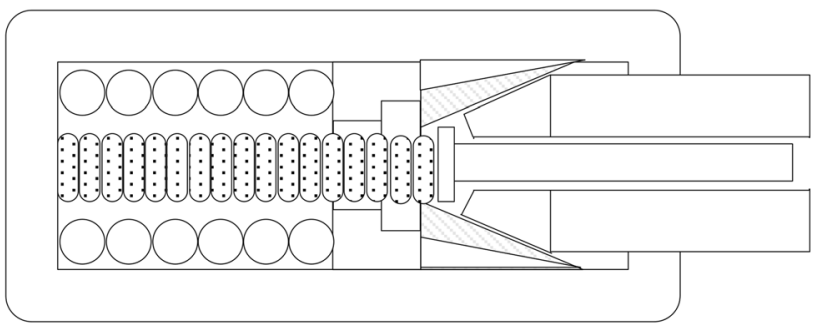

(a)

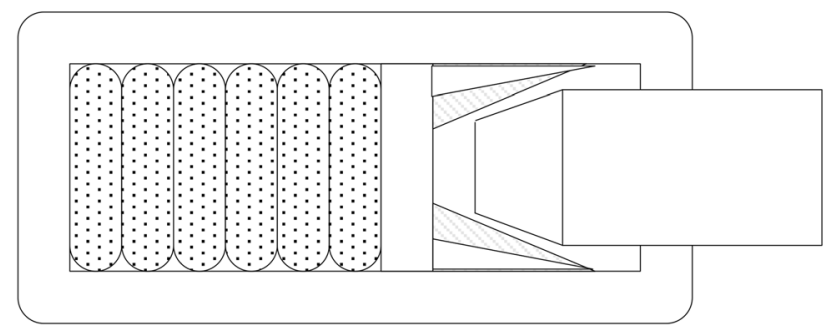

(b)

Fig. 5 Hexagonal three friction shoe polymer draft gear (a) and square four friction shoe steel spring draft gear (b)

working area of the FR8RAIL project in the European Union's Shift2Rail initiative included the development of a new Automatic Coupling [14]. The FR8RAIL project specified compatibility with the existing SA3 coupler as a clear requirement [15]. The website states that a new version of the SA5 coupler is under development with focus on enhancing functionality [14]. This initiative has now progressed to the FR8RAIL II project which is scheduled for completion in mid-2021, and also specifies an automatic coupler as a requirement in WP01 [16].

More recent developments published in a report on September 2020 of the new version of SA5 coupler specify electric-driven uncoupling actuation that can be controlled from the locomotive or from an external control hub [17]. The digitisation aspect of the project requires electronic power and data signal pass through from one wagon to another enabling the coupler to power up the electronic hardware onboard [17]. The electronic power and data connections must be able to be connected and disconnected without manual intervention [17]. The specifications of this coupler far exceed the current capability of freight couplers used world-wide including Janney coupler. Most railways intend to eventually phase out the buffer and chain coupler, so the buffers will not be further included in this review.

Arguably, the most important component in the wagon connection is the draft gear (or buffer) that provides connection stiffness and damping. Damping is provided by either friction, polymer hysteresis or viscous forces from fluids. Stiffness is provided by either steel or polymer springs and by fluid stiffness in hydraulic systems. Slack is provided by the dimensional tolerance of components. From these basic principles, products can be categorised into a number of "product groups" as shown in Table 4. Table 4 shows the product groups available on the market and their application in the different rail industry groups ranging from heavy haul to passenger services.

Wagon connections transmit towing and braking forces (steady state forces) and provide the damping for impact forces. In heavy haul applications, the connection system 
Table 5 Association of American Railroads (AAR) compressive draft gears classifications

\begin{tabular}{|c|c|c|c|c|c|}
\hline No & Draft gear make and model & Type & $\begin{array}{l}\text { AAR } \\
\text { standard }\end{array}$ & Friction type & Spring type \\
\hline \multicolumn{6}{|c|}{ Compressive draft gear and yoke systems } \\
\hline 1 & Amsted Rail Endurance 325 Draft Gear [18] & $\begin{array}{r}\text { Polymer } \\
\text { spring }\end{array}$ & M-901E & Hexagonal & Polymer \\
\hline 2 & Amsted Rail Twin Pack Draft Gear [18] & $\begin{array}{r}\text { Polymer } \\
\text { spring }\end{array}$ & M-901E & N/A & Polymer \\
\hline 3 & Bradken Quikdraw Ultra-Lite $[19,20]$ & $\begin{array}{r}\text { Polymer } \\
\text { spring }\end{array}$ & & & Polymer \\
\hline 4 & $\begin{array}{l}\text { Cardwell Westinghouse Mark } 325 \text { [21], Mark } 50 \text { [21-25], } \\
\text { Mark 70E [25], Mark 558 [25, 26], Mark 75G } \\
{[21,25,27] \text { and Mark 90AT [25] }}\end{array}$ & Steel spring & $\begin{array}{l}\text { M-901J } \\
\text { M-901E } \\
\text { M-901G }\end{array}$ & Rectangular & Spring nest \\
\hline 5 & Cardwell Westinghouse Mark H-60 [21] & Steel spring & M-901G & $\begin{array}{l}\text { Rectangular } \\
\text { with } \\
\text { hydraulic } \\
\text { clutch }\end{array}$ & Spring nest \\
\hline 6 & $\begin{array}{l}\text { Cardwell Westinghouse Mark L [24] Cardwell } \\
\text { Westinghouse Mark L-R [24] }\end{array}$ & Steel spring & M-901E & Rectangular & Spring nest \\
\hline 7 & Cardwell Westinghouse Mark MT2 & Steel spring & M-901E & & \\
\hline 8 & Cardwell Westinghouse Mark R500 [21, 23, 24] & Steel spring & M-901E & Rectangular & Spring nest \& rubber tube \\
\hline 9 & Miner Crown SE $[23,24,28]$ Miner Crown TG $[23,24]$ & Steel spring & M-901E & Rectangular & Spring nest \\
\hline 10 & Miner Crown SG [23, 24, 29] & Steel spring & M-901G & Rectangular & Spring nest \\
\hline 11 & Miner Drawbar Gears-DrawGuard FT [30] & $\begin{array}{r}\text { Polymer } \\
\text { spring }\end{array}$ & M-901E & Rectangular & Round \\
\hline 12 & Miner RF-444-Obsolete $[23,24]$ & $\begin{array}{r}\text { Polymer } \\
\text { spring }\end{array}$ & M-901E & Hexagonal & Round \\
\hline 13 & Miner SL-76 [23, 24] & $\begin{array}{r}\text { Polymer } \\
\text { spring }\end{array}$ & M-901E & Hexagonal & Rectangular \\
\hline 14 & Miner TP-17 [31] & Polymer & Non-AAR & Nil & Round \\
\hline 15 & Miner TF-880 [23, 24] & $\begin{array}{r}\text { Polymer } \\
\text { spring }\end{array}$ & M-901E & Hexagonal & Round \\
\hline 16 & Sigra DynamIQ 742 Draft Gear [32] & $\begin{array}{r}\text { Polymer } \\
\text { spring }\end{array}$ & M-901E & Square & Round \\
\hline 17 & Sigra A.Stucki PowrGuard GX $[32,33]$ & Steel spring & M-901G & Rectangular & Spring nest \\
\hline 18 & Sigra A.Stucki PowRguard GXE $[32,33]$ & Steel spring & M-901G & Rectangular & $\begin{array}{l}\text { Spring nest with elastomer } \\
\text { insert }\end{array}$ \\
\hline 19 & Sigra A.stucki PowrGuard XE $[32,33]$ & Steel spring & M-901E & Rectangular & Spring nest \\
\hline \multicolumn{6}{|c|}{ Other draft gears } \\
\hline 1 & Amsted Rail Integral Cast Draft Sill [18] & Sliding sill & M-921A & N/A & N/A \\
\hline 2 & Amsted Rail Twin Pack Draft Gear System [18] & $\begin{array}{c}\text { Floating } \\
\text { plate }\end{array}$ & M-901E & N/A & Polymer \\
\hline 3 & Double Draft Gear System [34] & Innovation & Multiple & Multiple & Multiple \\
\hline 4 & Escorts Balanced Draft Gear Uystem [35] & Balanced & M-901E & Nil & Round \\
\hline 5 & OLEO Hydraulic Draft Gear [36] & Hydraulic & M-901K & Hydraulic & Hydraulic \\
\hline 6 & Strato Long Pocket Polymer System [37] & Polymer & & Nil & Rectangular polymer \\
\hline
\end{tabular}

consists of a coupler (used to connect rolling stock together) and a draft pack (provides the longitudinal suspension of the train). The draft pack consists of a draft gear, follower and yoke. The draft pack transmits towing and braking forces and provides damping, while the compressive draft gear and yoke system is an assembly that compresses the draft gear under both buff and draft forces. The compressive draft gear and yoke system is discussed in detail in Sect. 5. 
There are two common types of friction damper systems used in compressive draft gear and yoke systems, namely

(1) Hexagonal section in the draft gear housing with three friction shoes (wedges) as shown in Fig. 5a.

(2) Rectangular section in the draft gear housing with four friction shoes (wedges) as shown in Fig. 5 b.

Friction provides large damping forces at very low loading speeds. Static and dynamic friction has been shown to give friction draft gears the characteristic of stiffening as the speed slows. Due to the geometry, the friction is proportional to the force and changes due to speed [6].

The other major component of the friction draft gear is the spring. There are three spring types present in friction draft gears, these being (refer to Table 5):

(1) A steel spring nest similar to the Wabtec Mark 50 and the Miner Crown SE.

(2) A rectangular polymer spring similar to the Miner SL-76.

(3) A circular polymer spring similar to the Miner TF880 and the Amsted Rail Endurance 325.

Steel springs are characterised by a linear stiffness until they reach the hard limit. The characteristics of steel springs do not change with loading speed. To achieve different stiffnesses during travel, steel springs can be arranged with different free lengths. This allows different springs to engage at different positions. Conversely, polymer springs give a nonlinear spring characteristic and change behaviour with both temperature and loading speed. A list of draft gears that are typically used in compressive draft gear and yoke systems is provided in Table 5. Draft gears included in the table are manufactured by companies including Amsted, Bradken, Cardell Westinghouse, Miner and Sigra.

There are several modern innovations, passenger and unique draft gears available on the market which are listed as "Other draft gears" in Table 5. These draft gears are discussed in detail later in this document. Balanced draft gear systems are used in passenger and light rail applications. Double draft gears and long polymer draft gear systems are modern innovations for freight trains.

Buffer and chain connections were used in the pioneer railway days, and it is assumed the free slack (slack action or gaps between wagons) assisted getting the train into motion. Free slack has remained in some designs in wagon connection systems and is still evident today in the Janney coupler which was first developed in 1893 [1, 7]. The buffer and chain, link and pin, and Janney coupler all have free slack as part of the design.

Slack allows the moving vehicles to assist the locomotive in overcoming the stationary rolling resistance by using the momentum and impacts of the moving vehicles to help start the motion of stationary vehicles. For example, in a train that is compressed together (that is, as close together as possible without compression of the draft gears-no free slack), the following events would take place as motion begins:

(1) The locomotive would propel forward.

(2) The slack would be taken up and the locomotive would pull the first wagon forward (overcoming the stationary rolling resistance with tractive effort and its momentum).

Table 6 Typical classification ranges of draft gears [23]

\begin{tabular}{llll}
\hline $\begin{array}{l}\text { Draft gear } \\
\text { class }\end{array}$ & $\begin{array}{l}\text { Static energy consumption, not less } \\
\text { than }(\mathrm{kJ})\end{array}$ & $\begin{array}{l}\text { Rated power consumption, not less than } \\
(\mathrm{kJ})\end{array}$ & $\begin{array}{l}\text { Maximum power consumption, not less } \\
\text { than }(\mathrm{kJ})\end{array}$ \\
\hline $\mathrm{T} 1$ & 30 & 70 & 90 \\
$\mathrm{~T} 2$ & 40 & 100 & 130 \\
$\mathrm{~T} 3$ & 60 & 140 & 190 \\
\hline
\end{tabular}

Table 7 Typical range of freight draft gears [24]

\begin{tabular}{|c|c|c|c|c|}
\hline $\begin{array}{l}\text { Draft gear } \\
\text { class }\end{array}$ & $\begin{array}{l}\text { Rated energy } \\
\text { capacity (kJ) }\end{array}$ & $\begin{array}{l}\text { Maximum energy } \\
\text { capacity }(\mathrm{kJ})\end{array}$ & $\begin{array}{l}\text { Apparatus stroke } \\
(\mathrm{mm})\end{array}$ & Featured types of wagons \\
\hline $\mathrm{T} 1$ & $60-80$ & $80-110$ & $70-120$ & $\begin{array}{l}\text { Gondola cars, platforms, covered for general cargo } \\
\text { destination, route trains }\end{array}$ \\
\hline $\mathrm{T} 2$ & $100-120$ & $130-160$ & $90-120$ & $\begin{array}{l}\text { Tanks, covered for valuable and ecologically dangerous } \\
\text { goods call }\end{array}$ \\
\hline $\mathrm{T} 3$ & $140-160$ & $190-220$ & 120 & Gas and chemical tanks for especially dangerous cargo \\
\hline $\mathrm{T} 4$ & $200-400$ & $400-800$ & $250-500$ & Specialisation cargo \\
\hline
\end{tabular}


(3) The locomotive and first wagon would then take up the slack and pull the second wagon forward.

(4) The momentum of the moving vehicles would progress along the train.

Slack action, the name given to the progressive increase or decrease of inter-wagon distance being propagated through the train, assists the locomotive to overcome the stationary rolling resistance by using the momentum of the moving vehicles. The rolling resistance of a stationary vehicle is higher than for a moving vehicle [21, 22], but

Table 8 Typical range of passenger draft gears [23]

\begin{tabular}{lll}
\hline $\begin{array}{l}\text { Draft } \\
\text { gear } \\
\text { class }\end{array}$ & $\begin{array}{l}\text { Maximum } \\
\text { force }(\mathrm{MN})\end{array}$ & $\begin{array}{l}\text { Energy consumption at a force not } \\
\text { exceeding the maximum, not less than } \\
(\mathrm{kJ})\end{array}$ \\
\hline P0 & 1.0 & 7 \\
P1 & 1.0 & 20 \\
P2 & 1.5 & 35 \\
P3 & 1.5 & 60 \\
P4 & 1.5 & 90 \\
\hline
\end{tabular}

data are limited. Slack allows a lower powered locomotive to overcome the stationary rolling resistance of each vehicle progressively. The Janney coupler design has not changed substantially since the patent was awarded to Eli H Janney in 1873 (U.S. Patent \#138,405) [7].

Traction capabilities of locomotives have increased significantly and improvements in bearing design and materials have improved substantially since the days of pioneer railways. The increase in locomotive capacity means that larger groups of vehicles can be accelerated. The optimisation of slack action in regard to traction requirements could be a worthwhile review. No literature investigating this area of design was identified.

Another method of classifying draft gears was located in the Russian standards. The Russian Standards specify a categorisation system for freight draft gears as shown in Table 6. The Russian standard [23] (GOST 32913-2014) outlines the technical requirements and acceptance rules for draft gears and automatic couplers. The standard is applicable to Armenia, Belarus, Kazakhstan, Kyrgyzstan, Russia, Tajikistan and Ukraine and categorises the draft gears into the following categories (Table 7):

Table 9 International draft gear acceptance criteria

\begin{tabular}{|c|c|c|c|c|}
\hline No. & Test & Method & Standard requirements & Comment \\
\hline \multicolumn{5}{|c|}{ American acceptance criteria [30] } \\
\hline 1 & Official capacity test & Drop hammer test & M-901E & \\
\hline 2 & Endurance test & Drop hammer test & M-901E & \\
\hline \multirow[t]{2}{*}{3} & Sturdiness test & Drop hammer test & M-901E & \\
\hline & $\begin{array}{l}\text { Cushioning devices, end-of-car, non- } \\
\text { hydraulic }\end{array}$ & Car collision & M-921K & \\
\hline \multicolumn{5}{|c|}{ Chinese acceptance criteria $[31]$} \\
\hline 1 & Official capacity test & Drop hammer test & TB/T 1961-2006 & \\
\hline 2 & Endurance test & Drop hammer test & TB/T 1961-2006 & \\
\hline 3 & Sturdiness test & Drop hammer test & TB/T 1961-2006 & \\
\hline \multicolumn{5}{|c|}{ Russian acceptance criteria [32] } \\
\hline 1 & Pulling test & Drop hammer test & $\begin{array}{l}\text { GOST R } 55185 \\
\text { Appendix G }\end{array}$ & \\
\hline 2 & Static test & Load test & $\begin{array}{l}\text { GOST R } 55185 \\
\text { Appendix E }\end{array}$ & \\
\hline 3 & Life test & Drop hammer test & $\begin{array}{l}\text { GOST R } 55185 \\
\text { Appendix I }\end{array}$ & $\begin{array}{l}\text { One of tests } 3,4 \text { and } 5 \text { are } \\
\text { required }\end{array}$ \\
\hline 4 & Life test & Car collision & $\begin{array}{l}\text { GOST R } 55185 \\
\text { Appendix I }\end{array}$ & $\begin{array}{l}\text { One of tests } 3,4 \text { and } 5 \text { are } \\
\text { required }\end{array}$ \\
\hline 5 & Life test & Load test on a hydraulic press & $\begin{array}{l}\text { GOST R } 55185 \\
\text { Appendix I }\end{array}$ & $\begin{array}{l}\text { One of tests } 3,4 \text { and } 5 \text { are } \\
\text { required }\end{array}$ \\
\hline 6 & Car collision test & Car collision & $\begin{array}{l}\text { GOST R } 55185 \\
\text { Appendix L }\end{array}$ & \\
\hline 7 & Extreme temperature test (freight) & $\begin{array}{l}\text { Drop hammer test under extreme } \\
\text { temperatures }\end{array}$ & $\begin{array}{c}\text { GOST R } 55185 \\
\text { Appendix M }\end{array}$ & $\begin{array}{l}\text { Tests undertaken from }-60 \\
\text { to }+50^{\circ} \mathrm{C}\end{array}$ \\
\hline
\end{tabular}


T1-This class is designed for all goods types except dangerous goods. It also includes shunting locomotives weighing up to $100 \mathrm{t}$.

T2-This class is designed for specialised cars carrying valuable goods and dangerous goods.

T3-This class is designed for wagons carrying highly dangerous goods.

A thesis published by Koturanov [24] gives further detail about the classification system, specifically the apparatus stroke and the featured wagon types as shown in Tables 3 and 4.

The Standards also have a similar classification for passenger draft gears as shown in Table 8. It is a similar system to the freight system. It was difficult to determine the type of draft gear that the table represented; however the specification discusses the initial tightening force of the draft gear which could indicate a draw hook and buffer draft gear system. The standard specifies that the initial tightening force for apparatus of classes P1, P2, P3 is from 0.025 to $0.080 \mathrm{MN}$, and class $\mathrm{P} 4$ is from 0.025 to $0.200 \mathrm{MN}$. The coefficient of irreversible absorption of energy must be at least 0.3 .

A similar method of categorising draft gears is utilised by the Miner product range. The Miner TF-880, Crown SE and SL-76 are all classified as M901E Group J draft gears which are intended for heavy freight. Miner states that these draft gears provide superior cushioning and maximum protection of railcars [25-27]. The Miner Crown SG is classified as being under the M901G Group K AAR standard which is focused on intermodal cars [18]. Miner states that these draft gears provide maximum long-term protection and reliability. The other classification of Miner draft gears is specialty draft gears which is the Miner TP17 [28]. The Miner TP-17 is listed as a draft gear that is not normally covered by Miner's current draft gear line. This draft gear is not approved by the AAR.

\section{Draft gear acceptance standards}

There is a range of acceptance criteria for draft gears accepted in difference countries. These acceptance criteria are documented in the appropriate standards. There are a vast number of standards and acceptance criteria utilised throughout the world. This review focuses on the major players being America, China and Russia, as shown in Table 9 with definitions of the tests provided in Table 10 . Britain and Europe have not been included in this review. Many European countries still utilise the draw hook and buffer couplings. Australia and India are also not discussed as both these countries utilise the Association of American Railroads Standards for Freight Draft Gears [29]. The focus of this review is on the major players in the global rail industry.

Table 9 shows that the Russian acceptance criteria for draft gears have several extra tests that are not required in any other country. The pull test under different temperatures is quite unique but demonstrates the harsh environment that these draft gears operate in. The Russian acceptance criteria also require different types of tests including car collision tests.

It can be seen that the Chinese and American acceptance standards have many similarities as they both utilise the drop hammer test as the primary acceptance criteria (Table 10).

Table 10 Draft test method definitions

\begin{tabular}{|c|c|}
\hline Test method & Definition \\
\hline Drop hammer test & $\begin{array}{l}\text { The drop hammer test is a vertical drop test or vertical drop weight impact test. The test consists of a dropping a } \\
\text { defined mass from a given distance onto the specimen. The mass is on vertical rails to ensure safety. The } \\
\text { displacement and reaction force under the specimen are recorded over time. These measurements allow the } \\
\text { displacement versus reaction force to be plotted giving a drop hammer performance graph for each draft gear } \\
\text { as shown in Sect. 5-7. The test is defined in [30-32] }\end{array}$ \\
\hline Car collision & $\begin{array}{l}\text { The car collision test is used to measure the run-in behaviour when two cars collide. Typically, this consists of } \\
\text { two wagons, one wagon is stationary and the other accelerates down a defined grade to reach a given speed } \\
\text { due to gravity. This test is similar to the drop hammer test but is more realistic because actual wagons are } \\
\text { used. Typically, the change of inter-wagon distance and reaction force are recorded over time. A wide range } \\
\text { of measurements can be recorded due to the nature of the test. The test is outlined in }[30,32]\end{array}$ \\
\hline Load test & $\begin{array}{l}\text { The load test is a static load test as defined by [32]. It consists of a maximum static force of at least } 2500 \mathrm{kN} \\
\text { being applied to the device. Measuring movement of the devices of at least full stroke of the apparatus, as well } \\
\text { as measuring instruments [32] }\end{array}$ \\
\hline $\begin{array}{l}\text { Drop test under extreme } \\
\text { temperatures }\end{array}$ & $\begin{array}{l}\text { This test is a requirement of [32]. It is the same test as outlined previously but under extreme conditions } \\
\text { being }-60 \text { to }+50{ }^{\circ} \mathrm{C} \text {. This is due to the extreme operating environment that Russian rolling stock operate } \\
\text { in }\end{array}$ \\
\hline
\end{tabular}




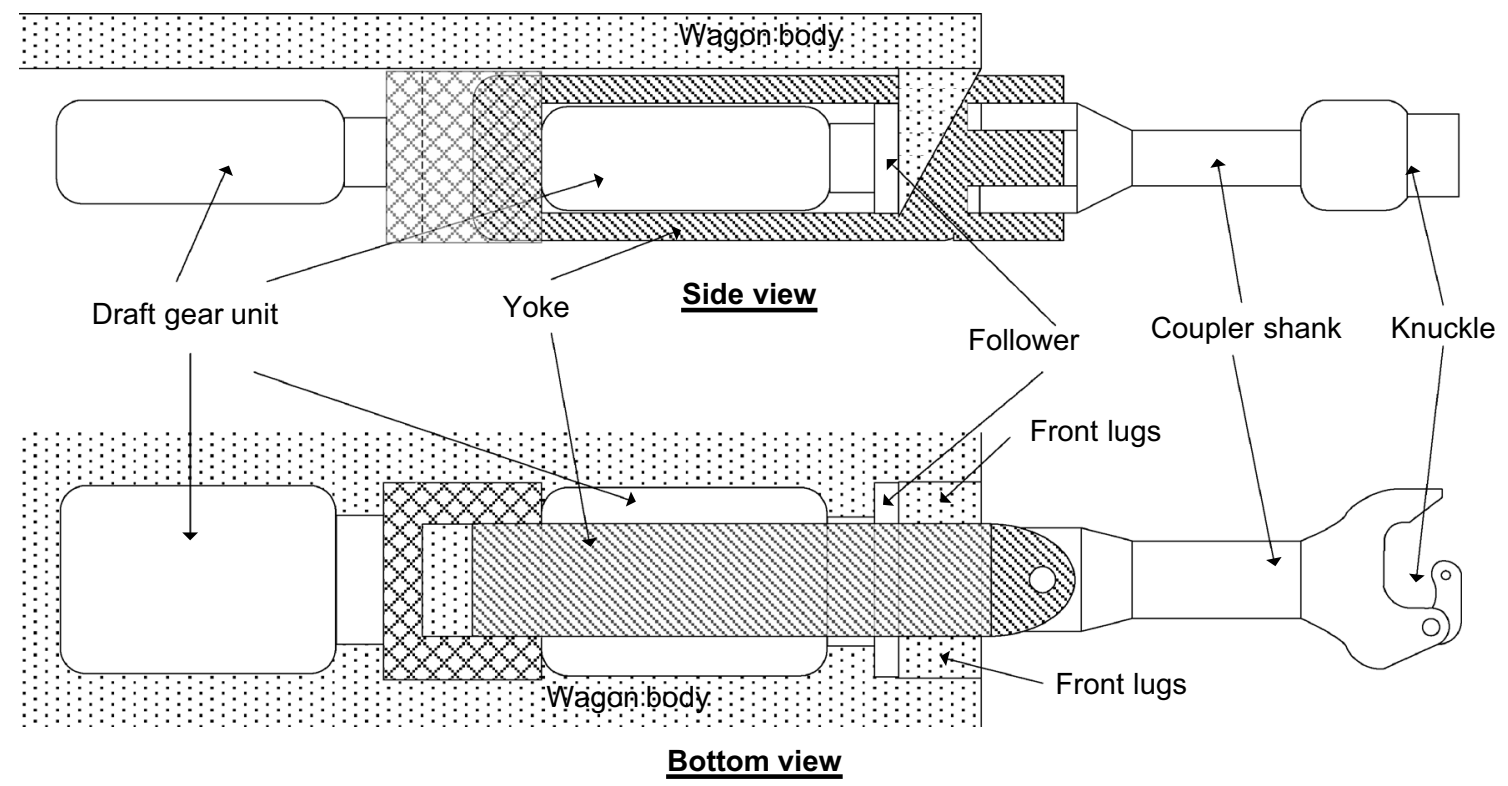

Fig. 6 Auto-coupler systems with compressive draft gear and yoke components

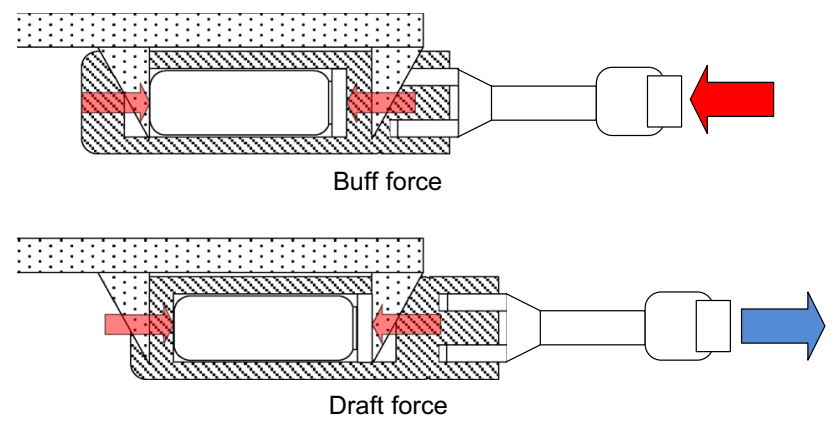

Fig. 7 Buff and draft force for auto-coupler systems with compressive draft gear and yoke

Table 11 Draft gear pocket sizes [34, 35]

\begin{tabular}{ll}
\hline Name & Length $(\mathrm{mm})$ \\
\hline Short pocket & 236 \\
Standard pocket & 625 \\
Long pocket & 924 \\
Longer pocket & 1238 \\
\hline
\end{tabular}

\section{Auto-coupler systems with compressive draft gear and yoke}

A typical auto-coupler system consists of the auto-coupler, compressive draft gear and yoke. The draft gear is secured in the wagon body via the front and rear lugs as shown in Fig. 6.

The yoke is a key component of the compressive draft gear and yoke design, which wraps around the draft gear

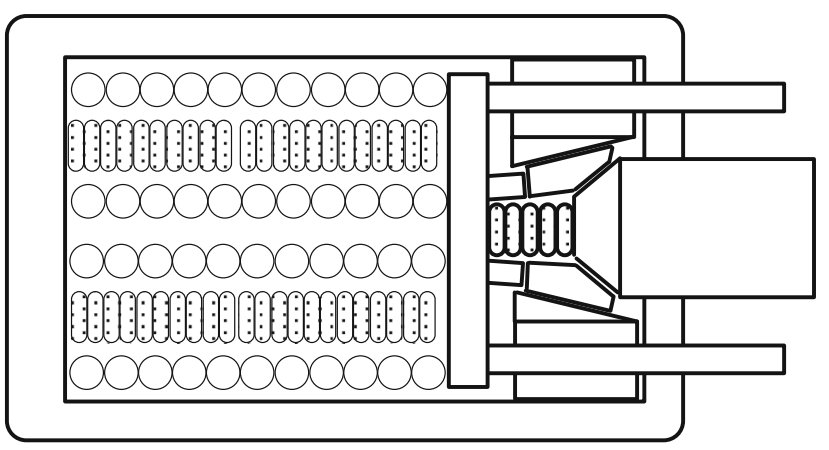

Fig. 8 Friction wedge and plate type [36]

and follower plate. When a compressive (buff) force is exerted onto the coupler, the yoke compresses the draft gear between the rear lugs and the follower plate. Similarly under a tensile (draft) force the yoke pulls on the rear of the draft gear which compresses the draft gear against the follower plate and the front lugs [33]. This behaviour is shown in Fig. 7 for both scenarios.

This concept is typically used in freight services. The auto-coupler systems with compressive draft gear and yoke allow a single draft pack to provide stiffness and damping forces in both directions, resulting in a compact design with minimal duplication of components. The standard draft gear sizes, typical of AAR and similar railway systems, have been defined and are shown in Table 11. A standard draft gear is $625 \mathrm{~mm}$ in length and is listed as a standard pocket in Table 11.

Dynamic testing is used to evaluate draft gear products. It is used in the evaluation process and its purpose is to rate performance and durability of the draft gear. The drop 
Table 12 Performance data of typical steel spring and friction damper systems (converted to metric units) [37]

\begin{tabular}{lllllll}
\hline Name of system & $\begin{array}{l}\text { Official capacity } \\
(\mathrm{kN} \cdot \mathrm{m})\end{array}$ & $\begin{array}{l}\text { Energy dissipated } \\
(\mathrm{kN} \cdot \mathrm{m})\end{array}$ & $\begin{array}{l}\text { Peak travel } \\
(\mathrm{mm})\end{array}$ & $\begin{array}{l}\text { Energy dissipation } \\
\text { efficiency }(\%)\end{array}$ & $\begin{array}{l}\text { Peak force } \\
(\mathrm{kN})\end{array}$ & $\begin{array}{l}\text { Total weight } \\
(\mathrm{kg})\end{array}$ \\
\hline $\begin{array}{l}\text { Cardwell Westinghouse } \\
\quad 56\end{array}$ & 42 & 78 & 75 & 1615 \\
$\quad \begin{array}{l}\text { Mark 50 } \\
\text { Miner Crown SE }\end{array}$ & 53 & 47 & 80 & 89 & 175 \\
Sigra PowRguard XE & 55 & 54 & 78 & 98 & 1461 \\
\hline
\end{tabular}

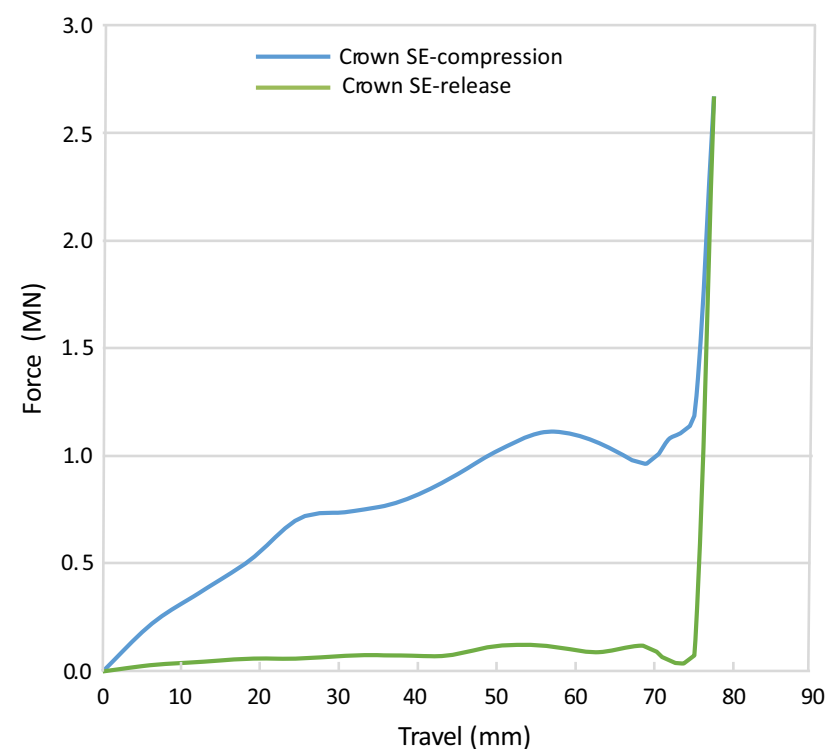

Fig. 9 Miner Crown SE drop hammer performance graph (replotted after [25])

hammer test is required to be performed utilising the AAR M-901 series draft gear testing. The method of testing is to drop a weight of $12.27 \mathrm{t}(27,000 \mathrm{lb})$ onto the draft gear. The weight is on runners similar to a press. The base of the machine is equipped with a load cell to measure reaction force. A linear potentiometric displacement transducer measures draft gear travel. The system then records the outputs from the transducers.

Other tests which are used include the wagon impact test and pendulum test. The wagon impact test is where wagons are tested via being run into an obstacle on a test track. This typically consists of utilising an inclined ramp to accelerate the impact wagon. The wagons are instrumented to record the data. The pendulum test is when a pendulum is utilised for the impact test.

The following sections discuss the various types of compressive draft gear systems.

\subsection{Draft gears with steel springs and friction dampers}

A diagram of a typical friction wedge and friction plate type draft gear (two stage damping) with steel springs is

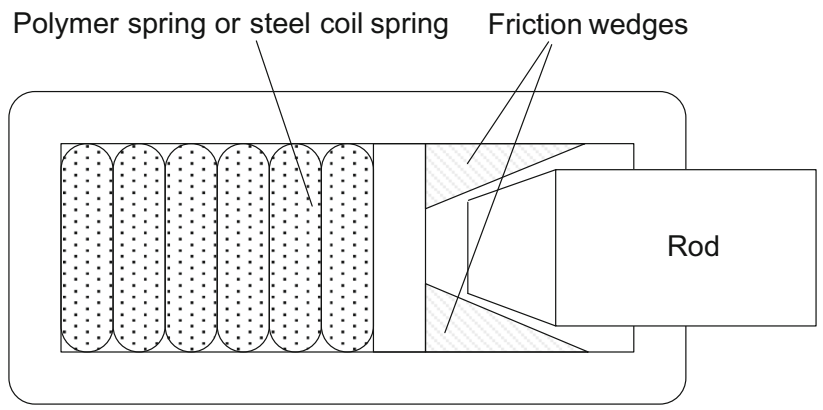

Fig. 10 Typical polymer spring and friction damper draft gear [36]

shown in Fig. 8. These draft gear systems are typically a rectangular cross-section design. The draft gear with steel springs and friction dampers consists of a housing with a main steel spring nest and friction damper components. As shown in Table 4 this type of draft gear forms the majority of the products available on the market, so it can be assumed that their adoption is widespread in industry. In 2014, Wu et al. [6] did state that the friction draft gear is the most widely used draft gear and that the situation is expected to last for a considerable period of time. It was not stated if this relates to the steel spring or polymer spring system.

Table 12 shows the performance data for some typical steel spring and friction damper systems available. Figure 9 shows the drop hammer performance graph of the Miner Crown SE [25]. The force peaks above 2.5 MN at full deflection at around $75 \mathrm{~mm}$ and has an official capacity of $46 \mathrm{~kJ}$ in a drop hammer test. Draft gears of this type typically consist of a spring nest in a rectangular housing with two friction wedges and two friction plates.

To better understand Table 12 and Fig. 9 and how they relate to each other, the following definitions are provided:

(1) Official capacity-The energy equal to the area below the blue line in Fig. 9.

(2) Energy dissipated-The energy equal to the area between the blue and green line in Fig. 9.

(3) Peak travel-The maximum distance that the draft gear can compress. 
Table 13 Performance data of some typical polymer spring and friction damper systems (converted to metric units)

\begin{tabular}{|c|c|c|c|c|c|c|}
\hline Name of system & $\begin{array}{l}\text { Official rating } \\
\text { travel }(\mathrm{mm})\end{array}$ & $\begin{array}{l}\text { Official } \\
\text { capacity } \\
(\mathrm{kN} \cdot \mathrm{m})\end{array}$ & $\begin{array}{l}\text { Reaction force at } \\
\text { rating travel }(\mathrm{kN})\end{array}$ & $\begin{array}{l}\text { Maximum } \\
\text { travel }(\mathrm{mm})\end{array}$ & $\begin{array}{l}\text { Capacity at maximum } \\
\text { travel }(\mathrm{kN} \cdot \mathrm{m})\end{array}$ & $\begin{array}{l}\text { Gear } \\
\text { weight } \\
(\mathrm{kg})\end{array}$ \\
\hline Miner SL-76 [27] & 77 & 64 & 2273 & 80 & 73 & 142 \\
\hline Miner TF-880 [26] & 74 & 61 & 2517 & 80 & 71 & 122 \\
\hline $\begin{array}{c}\text { Amsted Rail Endurance } \\
325 \text { Draft Gear [38] }\end{array}$ & 64 & 64 & 2237 & 82 & 98 & 125 \\
\hline
\end{tabular}

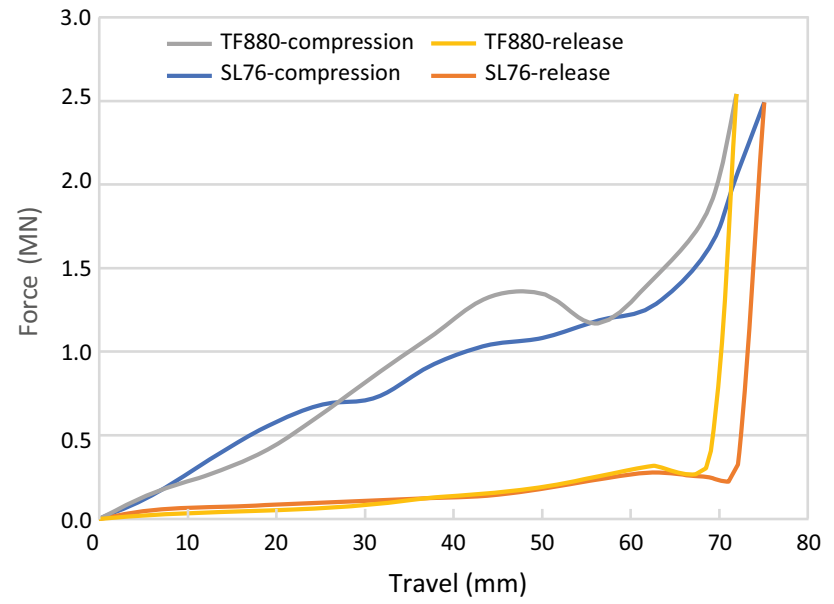

Fig. 11 Miner SL-76 and TF-880 drop hammer performance graph (replotted after [26, 27])

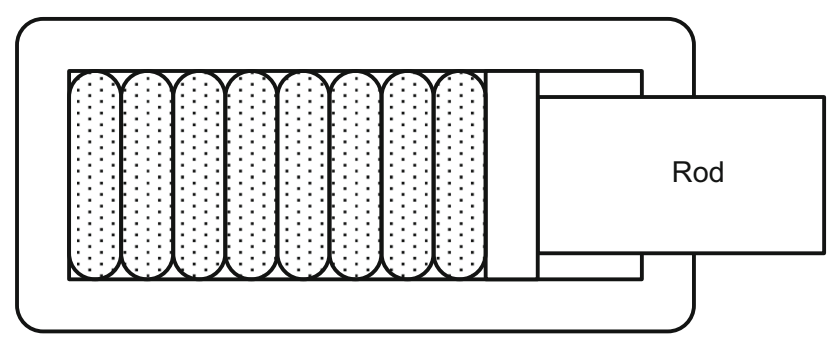

Fig. 12 Polymer spring draft gear [36]

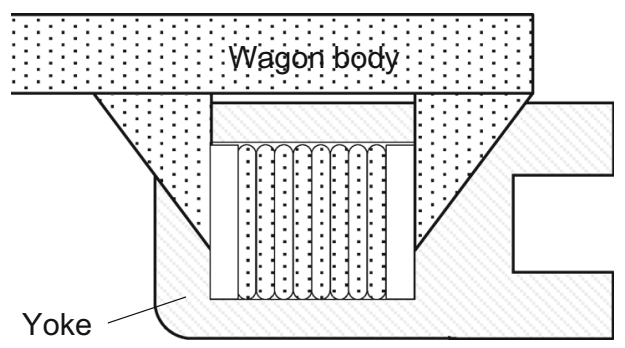

Fig. 13 Polymer spring draft gear installed in wagon body

(4) Energy dissipation efficiency-The ratio between the energy dissipated divided by the official capacity.

(5) Peak force-The maximum damping force that the draft gear can provide.

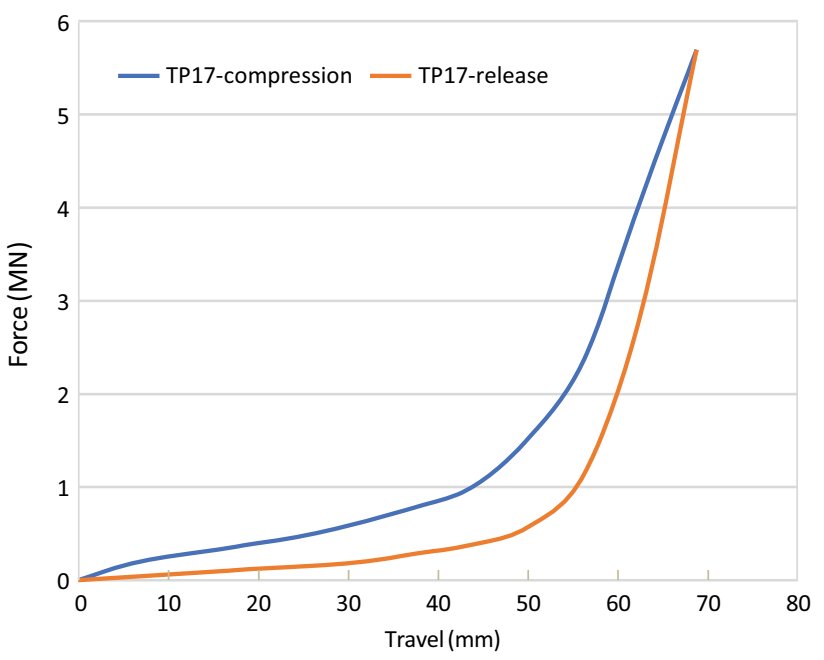

Fig. 14 Miner TP-17 drop hammer performance graph (replotted after [31])

\subsection{Draft gears with polymer spring and friction dampers}

The polymer spring and friction damper systems consist of a polymer spring and friction system. There are two basic types of these draft gears in production:

(1) Rectangular polymer spring with a hexagonal 3 shoe friction damper (e.g., Miner SL-76 [27]).

(2) Circular polymer spring with a hexagonal 3 shoe friction damper (e.g., Miner TF-880 [26] and Amsted Rail Endurance 325 Draft Gear [38]).

The rectangular polymer spring type consists of several individual polymer springs in a sandwich spring arrangement at the back-end of the draft gear package as shown in Fig. 10. At the front of the draft gear, it consists of a friction wedge assembly.

Performance data for three typical polymer spring and friction damper systems are shown in Table 13. Different designs create different performance characteristics. Polymer spring and friction damper systems typically have a higher reaction force at rating travel than steel springs and friction damper systems. 
Figure 11 shows a comparison of the Miner SL-76 [27] and TF-880 [26]. Both draft gears peak at approximately $2.5 \mathrm{MN}$ under full deflection, around $70 \mathrm{~mm}$. The most notable difference between the two drop hammer tests is that the stiffness of the TF- 880 draft gear becomes negative at approximately $45 \mathrm{~mm}$ and the force supported by the draft gear reduces. No publications or modelling describing this behaviour were found.

\subsection{Polymer spring draft gear}

The polymer spring draft gears consist of a polymer spring with no friction damping components, as shown in Fig. 12. It is typically installed similar to Fig. 13. Damping is provided by the hysteresis of the polymer material. There are two key service applications for polymer spring draft gears being freight and passenger service draft gears. For freight services, the Miner TP-17 draft gear is an example of a small pocket or short pocket design as defined in Table 11. Another freight polymer spring draft gear mentioned in literature is the Bradken quikdraw ultra-lite draft gear, but very little information could be identified on this

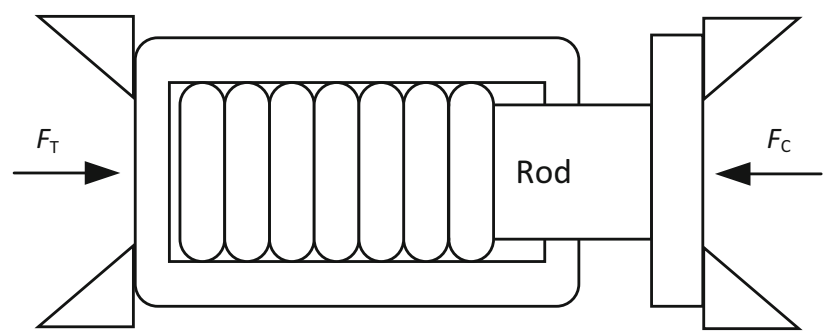

Fig. 15 Single pack type draft gear [41]

(a)

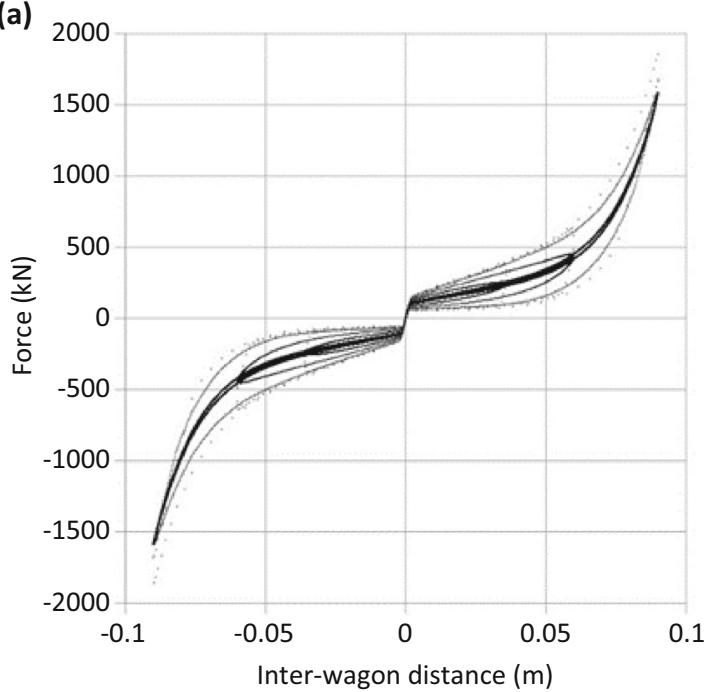

draft gear [39, 40]. A paper published in 2014 [40] discussed the short pack draft gear being used with draw bar connections and compared measured data and simulated data for low frequency vibration behaviour. The paper concluded that a significant improvement in low frequency vibration was achieved and hence might result in possible improvement in fatigue life. The travel of the quikdraw ultra-lite draft gear is extremely short, approximately $12 \mathrm{~mm}$.

The difference in compression and release of the two curves is due to the internal damping of the polymer, as

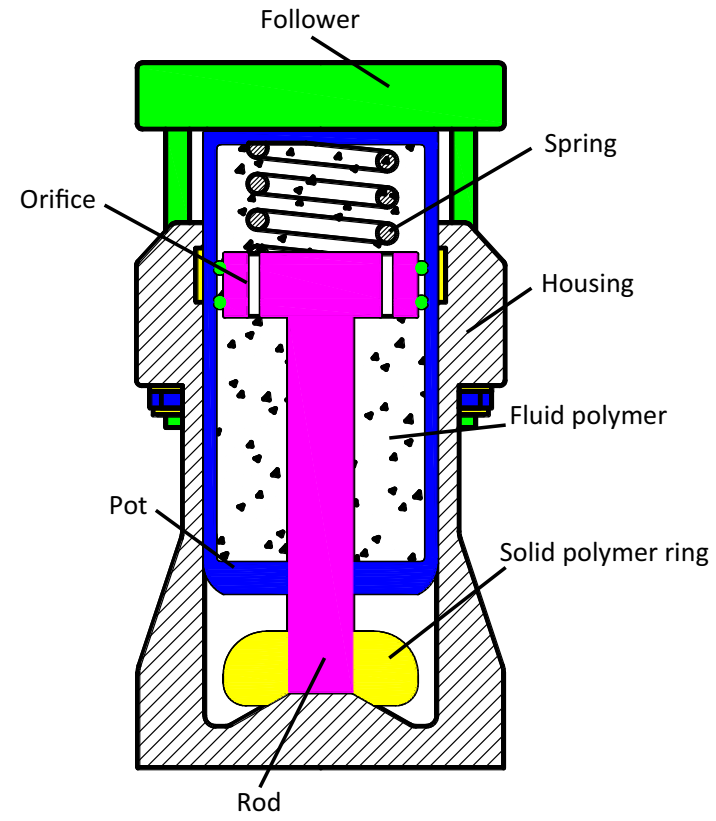

Fig. 17 Oleo hydraulic draft gear [44]

(b)

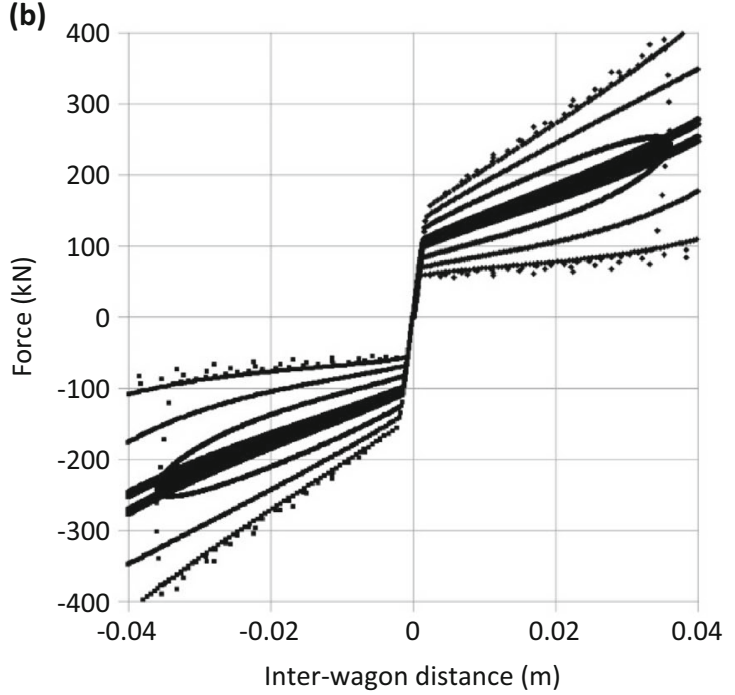

Fig. 16 Wagon connection model responses of single pack draft gear at $0.1,1.0$ and $10.0 \mathrm{~Hz}$ (a) and the zoomed-in graph (b) [41] 
Table 14 Comparison of performance data of hydraulic draft gears (converted to metric units)

\begin{tabular}{|c|c|c|c|c|c|c|}
\hline & $\begin{array}{l}\text { Official rating } \\
\text { travel }(\mathrm{mm})\end{array}$ & $\begin{array}{l}\text { Official } \\
\text { capacity (kJ) }\end{array}$ & $\begin{array}{l}\text { Reaction force at } \\
\text { rating travel }(\mathrm{kN})\end{array}$ & $\begin{array}{l}\text { Maximum } \\
\text { travel }(\mathrm{mm})\end{array}$ & $\begin{array}{l}\text { Capacity at } \\
\text { maximum travel }(\mathrm{kJ})\end{array}$ & $\begin{array}{l}\text { Gear } \\
\text { weight } \\
(\mathrm{kg})\end{array}$ \\
\hline Miner SL-76 [35] & 77 & 65 & 2273 & 80 & 73 & 142 \\
\hline Miner TF-880 [36] & 74 & 62 & 2517 & 80 & 71 & 122 \\
\hline $\begin{array}{l}\text { Amsted Rail Endurance } 325 \\
\text { Draft Gear [37] }\end{array}$ & 64 & 65 & 2237 & 82 & 98 & 124 \\
\hline $\begin{array}{l}\text { Oleo Hydraulic Draft Gear } \\
\text { [45] }\end{array}$ & 85 & 350 & -1500 & 85 & 407 & \\
\hline $\begin{array}{l}\text { Cardwell Westinghouse Mark } \\
50[19,20,46-48]\end{array}$ & 77 & 42 & 1614 & 77 & 55 & 174 \\
\hline Miner Crown SE [19, 20, 25] & 80 & 46 & 1461 & 80 & 52 & 176 \\
\hline
\end{tabular}

shown in Fig. 14. The polymer spring also does not have any negative slopes on the compression or release. It has a smooth compression and release curve. A typical drop hammer test of the Miner TP-17 is shown in Fig. 14.

The single pack draw gear system is another category of polymer spring draft gear typically used in passenger or light rail services. Single pack draft gears comprise a polymer (or elastomer) spring and a rod as shown in Fig. 15. The single pack draft gear is a polymer draft gear with a preload imposed. The preload is imposed by the wagon chassis [41]. The preload force must be overcome before the draft gear acts as a polymer spring ( $F_{\mathrm{c}}$ for compression and $F_{\mathrm{T}}$ for tension) as shown in Fig. 16. No OEM or test data could be identified in literature so the modelling of these draft gears has been presented.

Figure 16 shows the wagon connection model responses from a model developed for the single pack draft gear from [41]. We can see that once the pre-load force is overcome, the single pack draft gear acts the same as a polymer

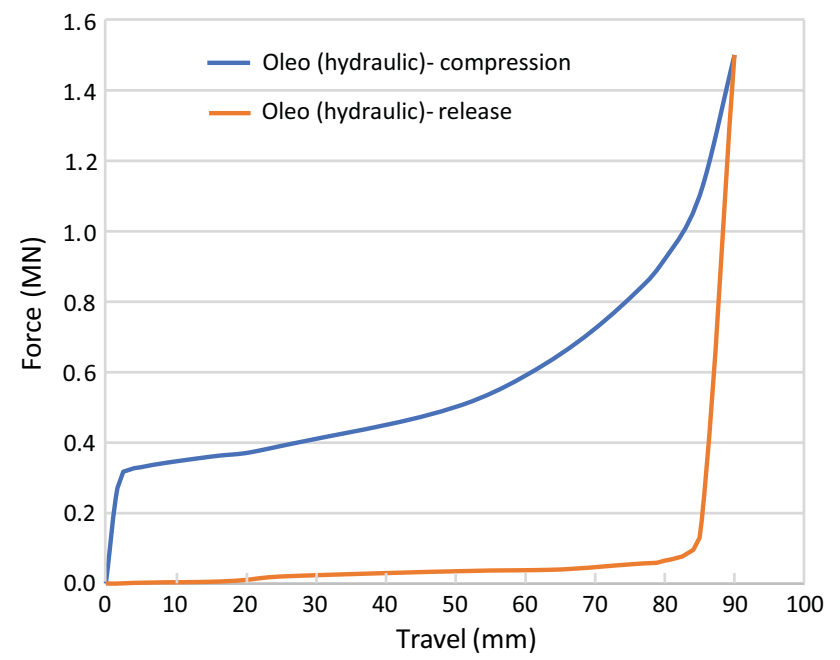

Fig. 18 Oleo draft gear drop hammer performance graph (replotted after [45]) spring. The zoomed in wagon connection model response graph (Fig. 16b) shows that a very similar response is present under compressive and tensile forces. This is expected due to the design of the single pack draft gear. Details on the modelling are provided in Sect. 11.1 of this paper as published by Cole et al. [41, 42].

\subsection{Hydraulic draft gear}

There are very few references discussing hydraulic draft gears [6, 43, 44]. In 2014, Wu et al. [6] discussed that it is a new type of draft gear and that the friction type draft gear is the most widely used. Patents could be identified on hydraulics draft gears from as early as the 1930s. However, the Oleo draft gear as shown in Fig. 17 is the only current product that could be identified. Wu's $\mathrm{PhD}$ thesis [43] discusses the draft gear and states that the draft gear has a fluid polymer dash pot, a solid polymer ring, a housing and an integrated follower. The presence of orifices also relates the draft gear characteristics to the velocity of the rod. The solid polymer ring provides extra stiffness when the draft gear reaches towards the end of the stroke. The coil spring provides recoil to return the draft gear to the uncompressed state [43].

Oleo [45] claims that their Oleo hydraulic draft gear has almost 5 times the energy absorption capacity compared to conventional draft gears. A comparison of the performance

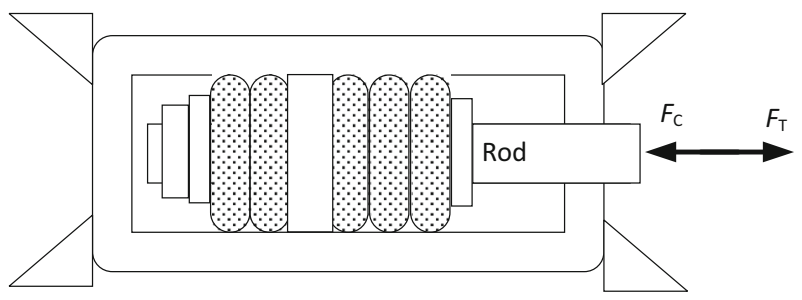

Fig. 19 Balanced type draft gear [41] 
(a)

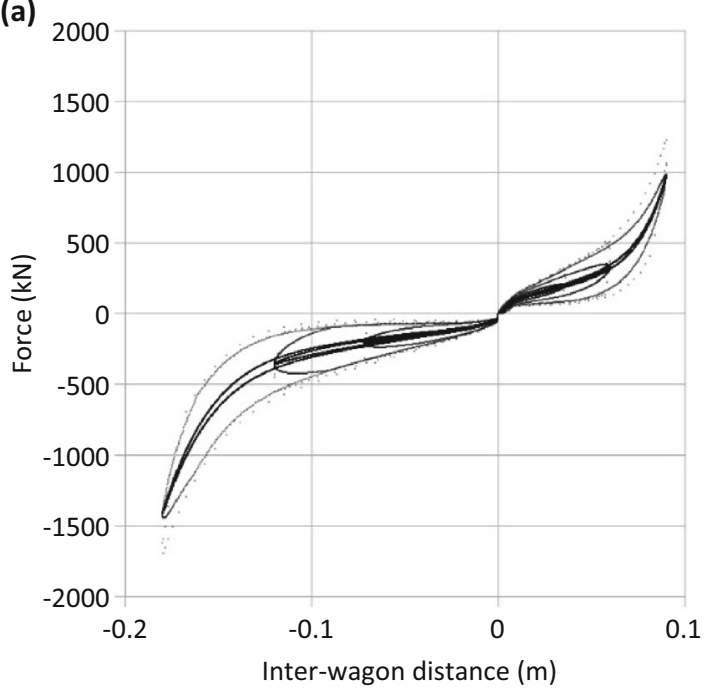

(b)

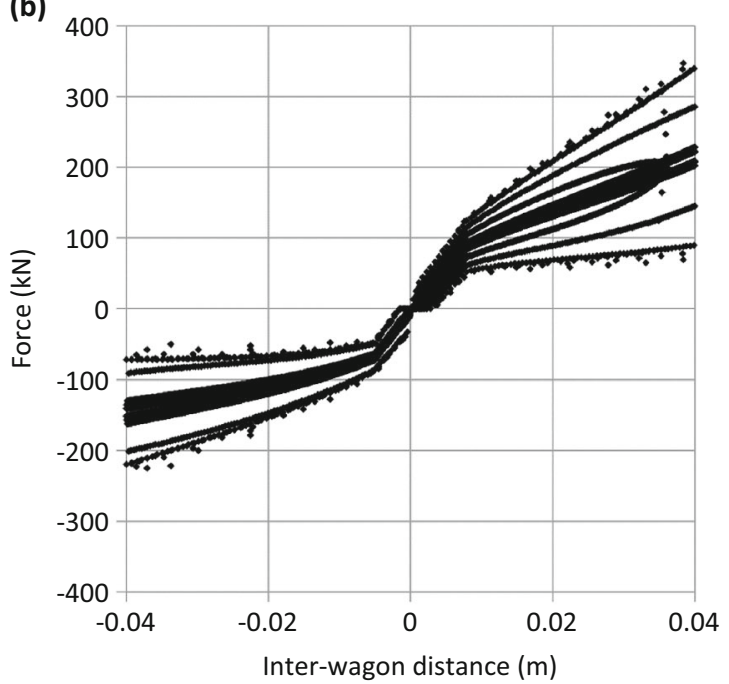

Fig. 20 Wagon connection models responses of balanced type draft gear at $0.1,1.0$ and $10.0 \mathrm{~Hz}$ (a) and the zoomed-in graph (b) [41]

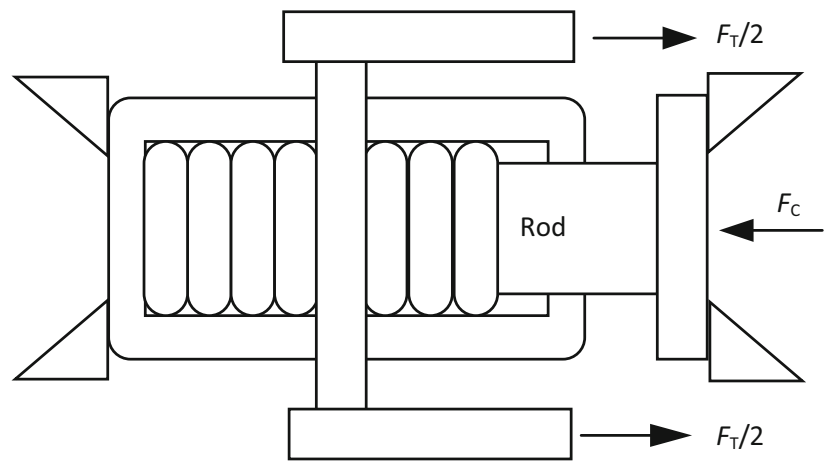

Fig. 21 Floating plate type draft gear [41]

data of the hydraulic draft gear compared to other draft gears is shown in Table 14.

The draft gear has a length of $575 \mathrm{~mm}$ [45] which is slightly shorter than a standard draft gear pocket $(625 \mathrm{~mm})$, refer to Table 11. It is unknown why this non-standard draft gear pocket size has been selected. The draft gear has a longer stroke than a conventional draft gear of approximately $85 \mathrm{~mm}$; however, the forces that it can accommodate are similar to a steel spring and friction damper system of approximately $1.5 \mathrm{MN}$ [45]. The static diagram for the hydraulic draft gear shows a smooth and consistent force profile during the compression and release phase.

The Oleo hydraulic draft gear has a smooth force profile as shown in the dynamic diagram in Fig. 18. As shown in Fig. 17, the design of the draft gear indicates that, if maximum travel is exceeded and hits the hard limit, there would be a severe and sudden increase in stiffness. The static diagram is expected to show a spike in forces as the draft gear acts like a steel on steel connection.

\section{Balanced type draw gear system}

The balanced type draw gear system comprises two polymer (or elastomer) springs and is typically used in passenger or light rail services. The balanced draw gear system consists of a rod with polymer springs on both sides of a plate as shown in Fig. 19. Balanced type draw gear systems consist of a rod which transmits the force to the polymer components. The draw gear system is pre-compressed by tightening the end nut [41]. This pre-compression results in increasing the stiffness of the draw gear system at small deflections where the polymer springs from both sides act together [41]. There are two manufacturers of these balanced draw gear systems being Dellner and Escorts. The Escorts website states that the balanced draft gear is an enhanced design which provides jerk free and smooth train operations [49].

The information provided by Escorts [49] states that the balanced draft gear can absorb $35 \mathrm{~kJ}$ (minimum) under dynamic force application of $1600 \mathrm{kN}$. Escorts [49] also states that the elastomeric pads offer high damping factors greater than $60 \%$. No further information is provided on the Escorts website.

A paper published by Cole in 2017 [41] shows the wagon connection model responses from a model developed for the balanced type draft gear as shown in Fig. 20. Figure 20b (zoom in graph) shows that there is a linear relationship until the opposing side of the draft gear no longer exerts a force. Once this distance is reached, the balanced type draft gear begins acting the same as a polymer spring. This is the case under compression and tension. For further information on modelling of these draw gear systems, please refer to Sect. 11.2. 
(a)

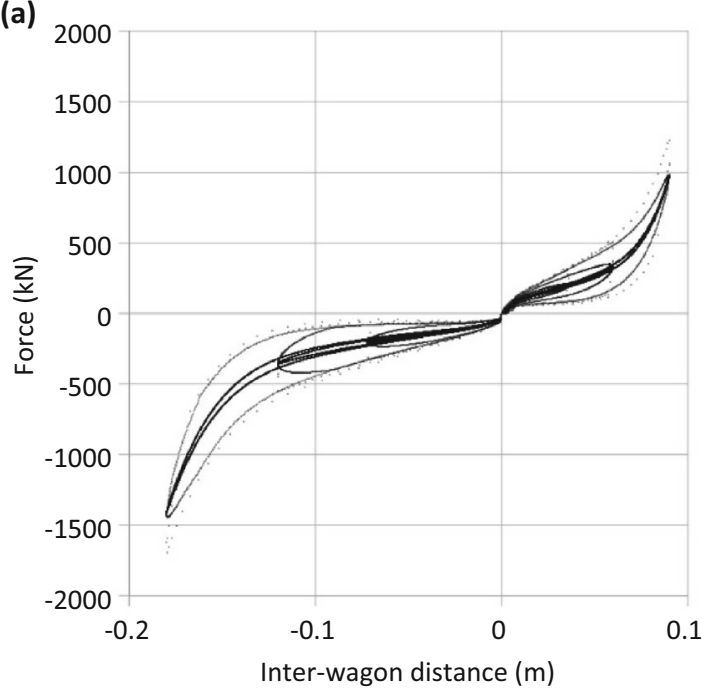

(b)

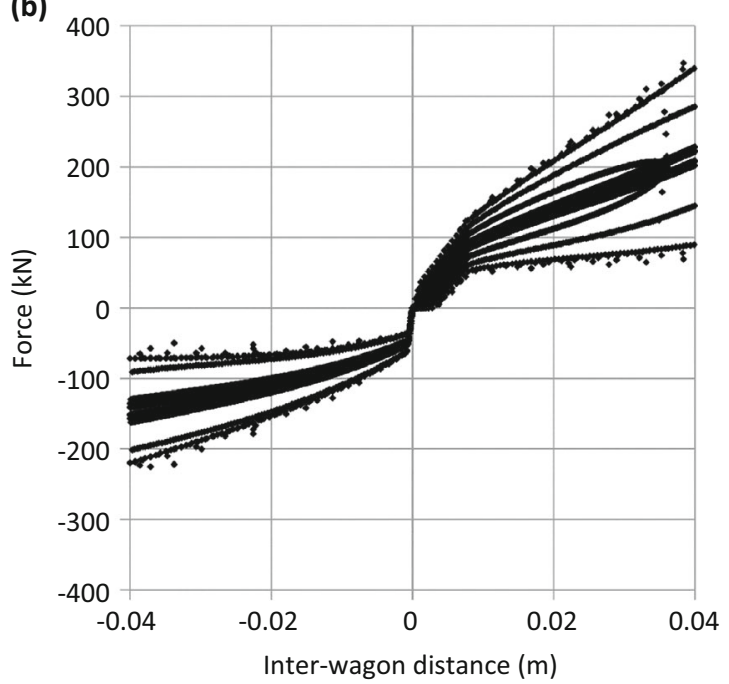

Fig. 22 Wagon connection models responses of floating plate draw gear at $0.1,1.0$ and $10.0 \mathrm{~Hz}$ (a) and the zoomed-in graph (b) [41]

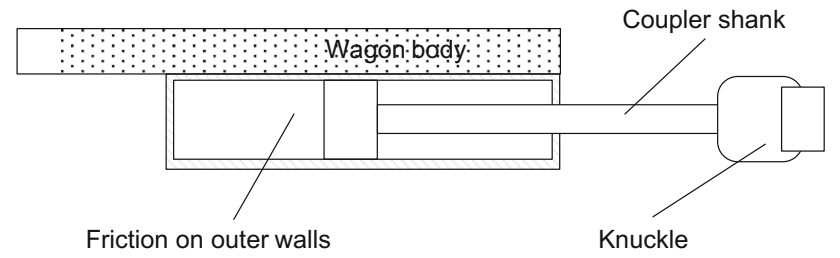

Fig. 23 Sliding sill cushioning system

\section{Floating plate draw gear system}

Floating plate draw gear systems are typically used in passenger and light rail services as shown in Fig. 21. Passenger twin pack or floating plate draw gears include the Amsted Rail Twin Pack Draft Gear [50] as shown in Fig. 21. Limited information is provided on this type of draw gear system on the company website. However, it is known that floating plate draw gear systems do exist particularly in passenger services and are referenced by literature $[41,42,50,51]$. When loaded in tension, the arrangement is the same as a balanced draw gear system. When loaded in compression, the configuration acts the same as a single polymer spring.

No published performance characteristics of these draw gear systems were located, but performance will just reflect the polymer characteristic and the configuration. A paper published by Cole in 2017 [41] shows the wagon connection model responses from a model developed for the balanced type draft gear as shown in Fig. 22. As discussed earlier, under compression $\left(F_{\mathrm{c}}\right)$ the floating plate draft gear acts as a polymer spring once the pre-load force is overcome, refer to Fig. 22. This is an identical to the single pack draft gear shown in Fig. 16. Under tension $\left(F_{\mathrm{T}}\right)$ the floating plate draft gear acts the same as the balanced draft gear as shown in Figs. 20 and 22. Details on the modelling are provided in Sect. 11.3 of this paper as published by Cole et al. [41, 42].

\section{Sliding sill cushioning system}

A sliding sill cushioning system as shown in Fig. 23 is a friction device without any spring elements to re-centre the device. The device can absorb a series of longitudinal forces. Damping is achieved through friction on the outer surfaces. If a series of longitudinal impacts are experienced in the same direction, the device can reach the end of travel resulting in the device no longer providing cushioning. The device then needs impacts in the opposite direction to recentre it. All sliding sill cushioning systems in the USA are governed by the AAR standard M-921A from the AAR Manual of Standards and Recommended PracticesFreight Car Draft Components [35]. Sliding sill cushioning devices include the Amsted Rail Integral Cast Draft Sills [50].

No modelling or performance characteristic information could be identified for sliding sill cushioning systems.

\section{Double draft gear system}

US patent 10086852 B2 [52] filed on the 2nd of October 2018 patents an improved energy management system which contains two draft gears in series as shown in Fig. 24. It consists of an extra draft gear mounted behind the existing one with a $\mathrm{C}$-shaped steel component to allow for the full yoke movement under buff force. When 
observing the mechanism of this draft gear system, two draft gears will be engaged when subjected to a compressive (buff) force, but only one draft gear will be engaged under tensile (draft) force. This will give two different behaviours under buff and draft.

US patent 10086852 B2 [52] shows velocity versus coupler force under different load conditions. Increased damping is achieved due to the increase in travel distance and energy dissipation of the draft gear being used. Different draft gear types may be used together to get variants of characteristics.
Performance characteristics can be varied by combining draft gears as series springs for the compression case. The tensile case is unchanged. If the draft gears are identical, the performance curve can be obtained by doubling the deflection data.

The modelling could be achieved by using the equations in Sect. 11 depending on the type(s) of draft gears installed. Note that neither performance curves nor modelling can be easily combined if the draft gears are different types.

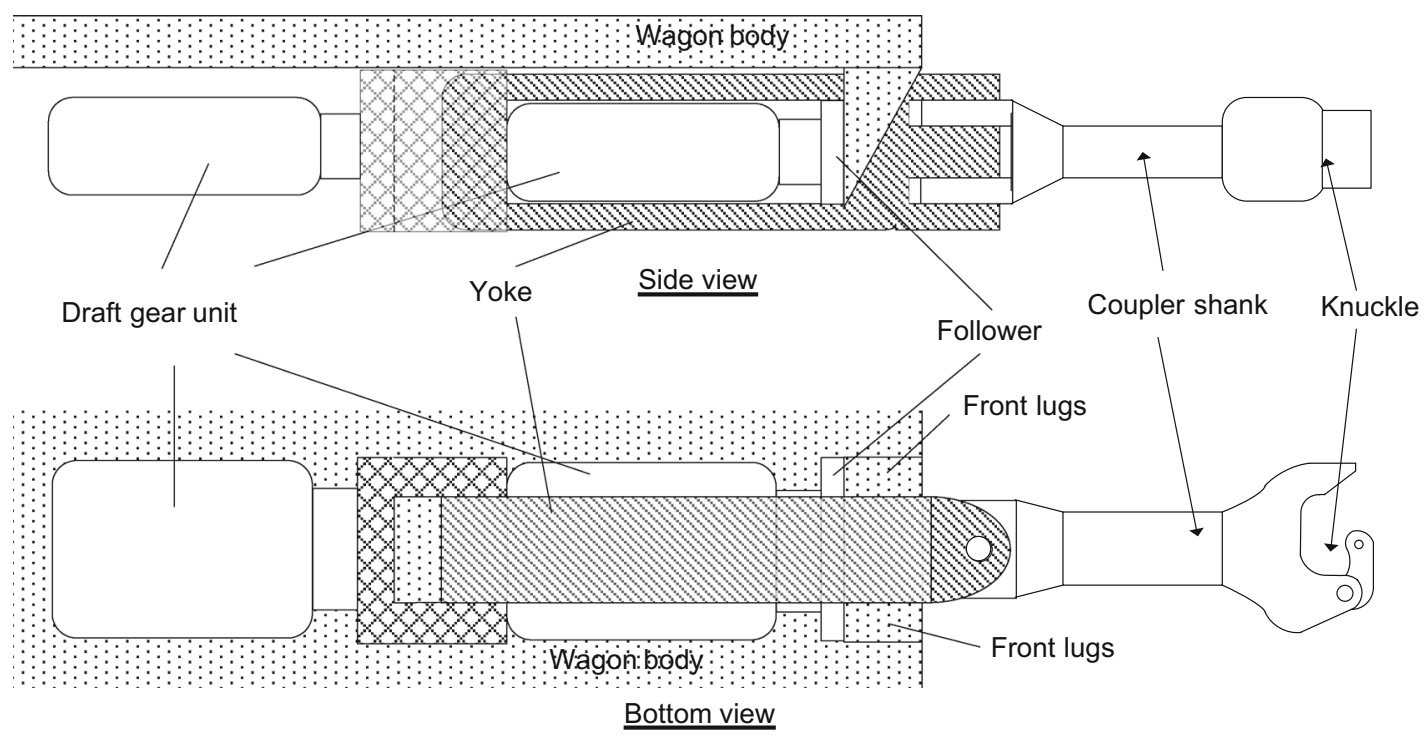

Fig. 24 Double buff pack type draft gear unit (redrawn after [52])

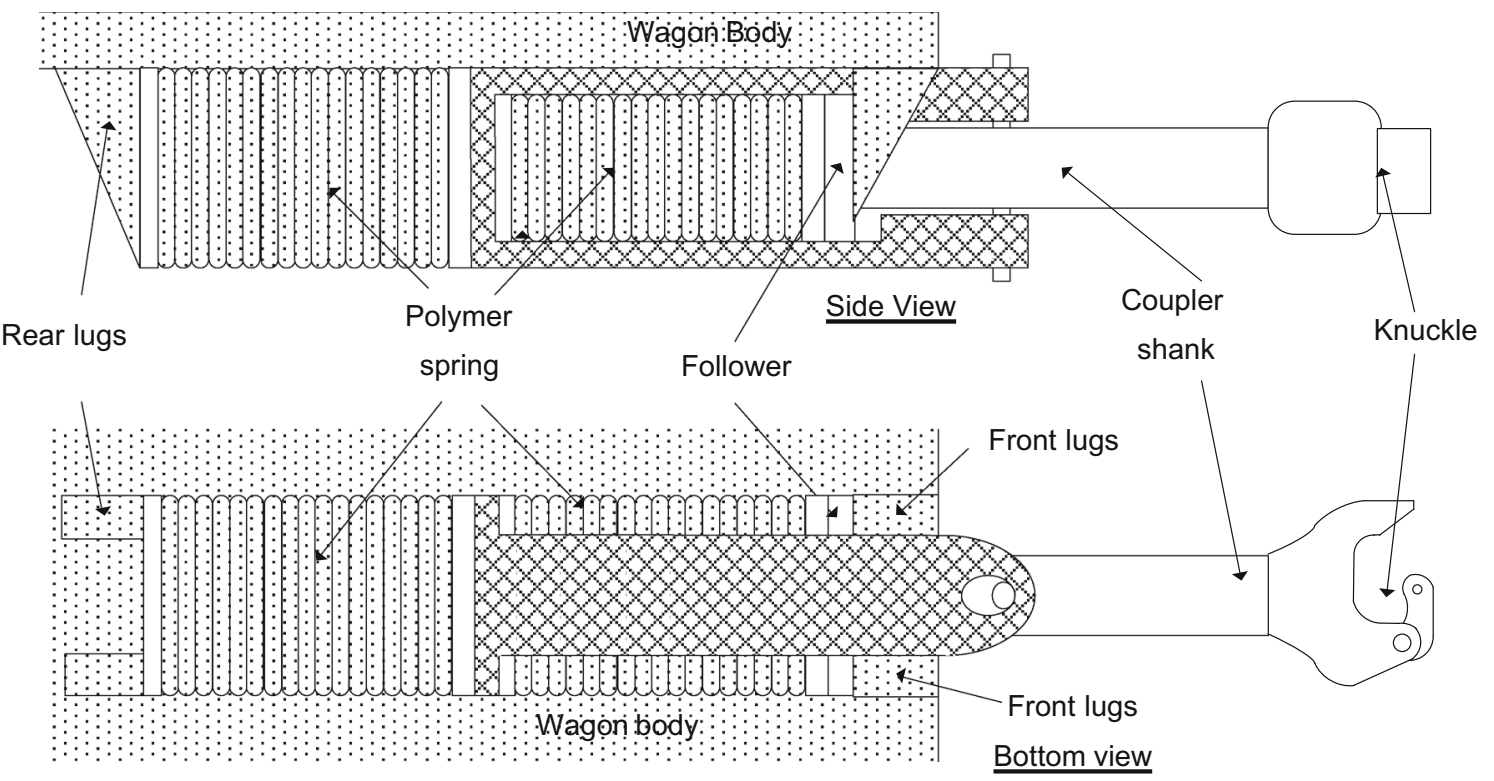

Fig. 25 Long pocket polymer (redrawn after [53]) 


\section{Long pocket polymer draw gear system}

Strato [60] filed US patent US 10308263 B1 on the 16th of November 2017. This patent outlines a long pocket polymer draw gear system as shown in Fig. 25. The patient outlines a selective cushioning device that is responsive to draft and buff forces. The design removes the yoke and associated components, allowing the area to comprise of polymer spring components.

No comparable work to Cole et al. [41, 42] and Wu et al. $[44,54]$ has yet been published on this type of draft gear model. It is assumed that it has been modelled utilising the aggregation of existing modelling components. The modelling could be achieved by utilising the polymer equation (Eq. (8) in Sect. 11 of this paper). This would consist of utilising different parameters under buff and draft. No additional published information could be identified for this type of draw gear system.

\section{Advanced modelling of draft gears}

A study of draft gear modelling reveals many different methods including look-up tables and various systems of equations [55, 56]. In 2017 a study was undertaken that compared the different train simulators used internationally. This study made some statements about draft gear modelling [55]. Nine simulators were compared in this study and $\mathrm{Wu}$ et al. noted that most longitudinal train simulators have one or more of the following simplifications:
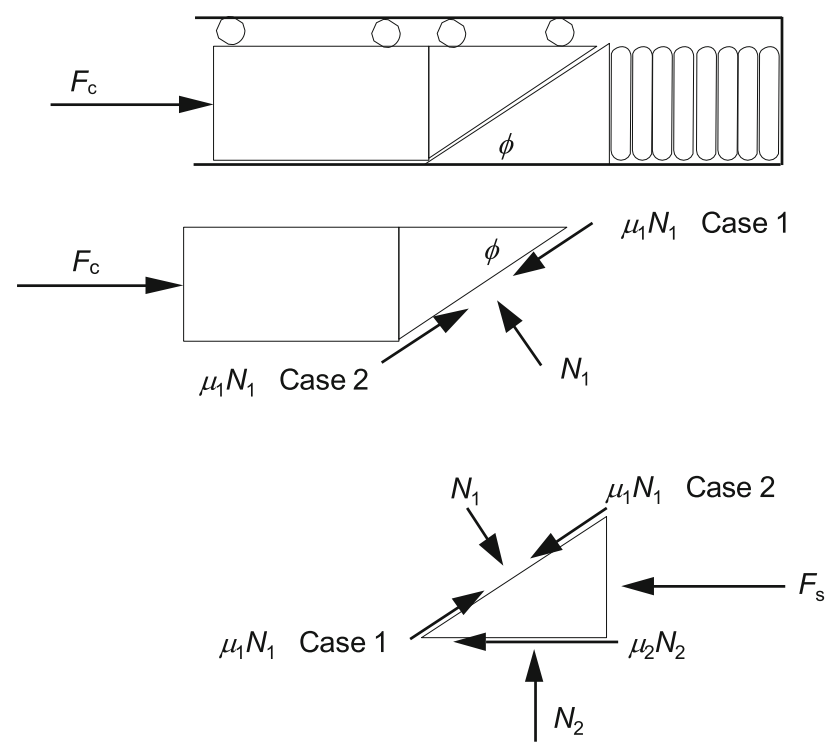

Fig. 26 Friction type draft gear unit [36]. $F_{\mathrm{c}}$ is compressive force and $F_{\mathrm{s}}$ the spring force, $\mu_{1}$ and $\mu_{2}$ are the friction coefficients, $N_{1}$ and $N_{2}$ are the forces perpendicular to the interface, and $\phi$ is the wedge angle
(1) Pre-load not considered.

(2) Characteristics approximated to look-up tables.

(3) Linear slope describing transitional characteristics between look up table curves.

This indicates that there are a number of assumptions often used for the draft gear models employed for most of the longitudinal train simulators. Conversely, Cole et al. [41, 42] and Wu et al. [44, 54] have used explicit equations for modelling the underlying physics of the components where possible [36, 41-44, 54]. The formulas that can be used to model draft gear behaviour have been developed and are published in [41, 42, 44, 54]. The models using the explicit equations are useful to this review to show the physics of the damping processes. The reader can refer to cited literature for other modelling techniques.

A more recent paper published in 2019 by Cole et al. [42] outlines an approach to model mixed combinations of draft gear systems. This includes combinations of single pack polymer draw gear systems, balanced polymer draw gear systems and nonlinear friction draft gears. Those authors state that, by modelling the couplers as a mass, it allows a method of connecting series springs and prevents the complexity of making equivalent series springs into one model. This method allows almost any draft gear or draw gear connection to be modelled [41, 42]. By utilising Eqs. (7) and (8) below, almost any complex series connection can also be modelled [42]. The negative sign is used in both those equations for the loading case and the positive sign is used for the unloading case [36].

A simple diagram of the friction polymer draft gear model is shown at the top of Fig. 26 which includes the rods, friction wedges, polymer spring and housing [36]. The remainder of Fig. 26 shows a simplified free body diagram of the compression phase of a polymer spring and friction draft gear and the associated variables used for the equations [36].

As shown in Fig. 26, there are two loading cases being case 1 and case 2. Under compression, if sliding action occurs, then only case 1 friction component applies. If a pre-jammed state exists, then case 2 applies. Case 2 is when the rod jammed in by the jamming action of the wedge. As discussed by [36] for certain wedge angles and coefficients of friction, wedges are self-locking.

Investigating the rod in Fig. 26 [36], we have

Case 1

$F_{\mathrm{c}}=N_{1}\left(\sin \phi+\mu_{1} \cos \phi\right)$,

Case 2

$F_{\mathrm{c}}=N_{1}\left(\sin \phi-\mu_{1} \cos \phi\right)$.

For self-locking, $N_{1}$ remains nonzero when $F_{\mathrm{c}}$ is removed, therefore [36]: 
$\sin \phi=\mu_{1} \cos \phi$

that is, if $\sin \phi<\mu_{1} \cos \phi$, then a negative force $F_{\mathrm{c}}$ is required to extend the rod [36]. It can be seen that, for selflocking there is

$\tan \phi<\mu_{1}$.

If the equations relating the wedge forces to the coupler force and polymer spring force are developed, assuming saturated friction states and direction shown in case 1 for $\mu_{1} N_{1}$ yields

$F_{\mathrm{c}}=F_{\mathrm{s}} \frac{\mu_{1} \cos \phi+\sin \phi}{\left(\mu_{1}-\mu_{2}\right) \cos \phi+\left(1+\mu_{1} \mu_{2}\right) \sin \phi}$.

For case 1 when $\mu=\mu_{1}=\mu_{2}$ and both surfaces are saturated, the equation reduces to [57]

$F_{\mathrm{c}}=\frac{F_{\mathrm{s}}(\mu \cot \phi+1)}{1+\mu^{2}}$.

In the event that there is no impending motion due to the seating of the rod wedge, the equation for a friction draft gear [42] (assuming $\mu_{1}=0$ ) is

$F_{\mathrm{c}}=\frac{F_{\mathrm{s}} \tan \phi}{\tan \phi \pm \mu_{2}}$.

The equation for a polymer draft gear as published in [42] is

$$
\begin{aligned}
F_{\mathrm{dg}}(x, v)= & F_{\mathrm{m}}\left(x_{\mathrm{a}}\right) \pm\left(C_{1}+C_{2}\left|\frac{x}{x_{\max }}\right|^{r_{1}}\left|\frac{v}{v_{\max }}\right|^{r_{2}}\right) \\
& {\left[1-\exp \left(-\lambda\left|\frac{v}{v_{\max }}\right|^{n}\right)\right], }
\end{aligned}
$$

where $F_{\mathrm{dg}}$ is draft gear force; $F_{\mathrm{m}}$ is the force from the nonlinear stiffness derived from the mean of loading and unloading curves; $x$ is the measures draft gear deflection, $x_{\mathrm{a}}$ is the draft gear polymer spring deflection and $x_{\max }$ is the measured hard limit; $v$ is the draft gear working velocity and $v_{\max }$ is the estimated maximum velocity; $C_{1}$ and $C_{2}$ are two viscous damping coefficients; $r_{1}$ is a tuning parameter for the $x$ position and $r_{2}$ is a tuning parameter for the velocity (or loading rate); $\lambda$ and $n$ are tuning parameters for nonlinear damping.

The formula for a polymer friction draft gear has not been provided in literature [41, 42, 44, 54]. However, it can be easily solved by substituting Eq. (8) into Eq. (7). This results in the formula for polymer friction draft gears being

$$
\begin{aligned}
& F_{\mathrm{dg}}(x, v)= \\
& \frac{\left[F_{\mathrm{m}}\left(x_{\mathrm{a}}\right) \pm\left(C_{1}+C_{2}\left|\frac{x}{x_{\max }}\right|^{r_{1}}\left|\frac{v}{v_{\max }}\right|^{r_{2}}\right)\left(1-\exp \left(-\lambda\left|\frac{v}{v_{\max }}\right|^{n}\right)\right)\right] \tan \phi}{\tan \phi \pm \mu_{2}} .
\end{aligned}
$$

A more detailed model for draft gears with steel springs and friction dampers located in literature was published by Wu et al. [54] in 2015 and is shown below:

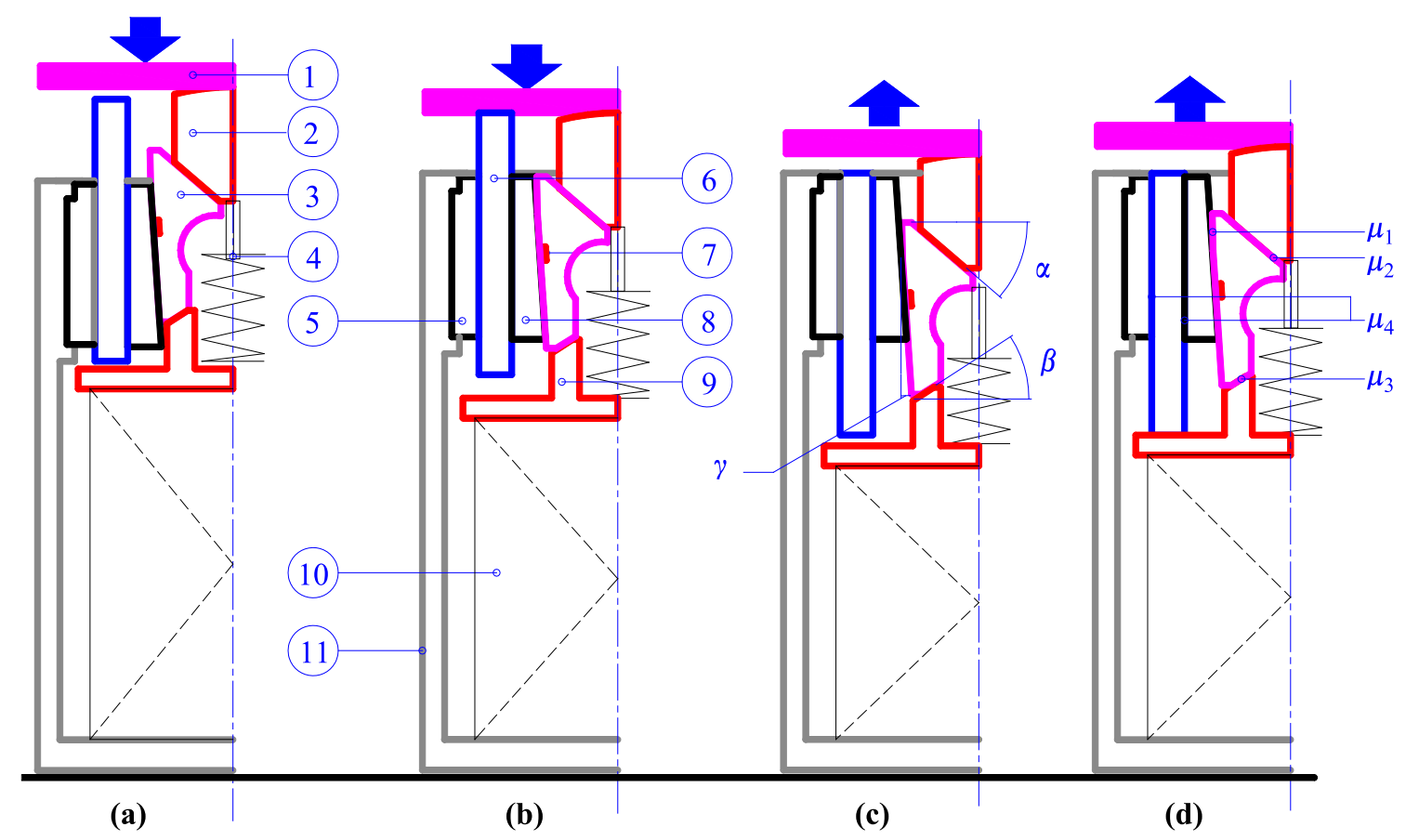

Fig. 27 Friction draft gear stages [54]: a loading stage 1 (L1), b loading stage 1 (L2), c unloading stage 1 (U1), and d unloading stage 2 (U2). Components labelled by circled numbers means, respectively, (1) follower, (2) central wedge, (3) wedge shoe, (4) release spring, (5) outer stationary plate, (6) movable plate, (7) lubricating metal, (8) inner stationary plate, (9) spring seat, (10) main spring, and (11) housing 
$F_{\mathrm{dg}, i}=\Psi_{i} F_{\mathrm{sm}}-\left(\Psi_{i}-1\right) F_{\mathrm{sr}}(i=1,2,3,4)$,

$\Psi_{1}=\frac{1+\tan \left(\beta+\arctan \mu_{3}\right) \tan \left(\gamma+\arctan \mu_{1}\right)}{1-\tan \left(\alpha+\arctan \mu_{2}\right) \tan \left(\gamma+\arctan \mu_{1}\right)}$,

$\Psi_{2}=\Psi_{1}+\frac{2\left(1-\mu_{1} \tan \gamma\right) \mu_{4}\left(\Psi_{1}-1\right)}{\mu_{1}+\tan \gamma}$,

$\Psi_{3}=\frac{1+\tan \left(\beta+\arctan \mu_{3}\right) \tan \left(\gamma+\arctan \mu_{1}\right)}{1-\tan \left(\alpha+\arctan \mu_{2}\right) \tan \left(\gamma+\arctan \mu_{1}\right)}$,

$\Psi_{4}=\frac{\left(\tan \gamma-\mu_{1}\right) \Psi_{3}}{\tan \gamma\left(1-2 \mu_{1} \mu_{4}+2 \mu_{1} \mu_{4} \Psi_{3}\right)+2 \mu_{4} \Psi_{3}-2 \mu_{4}-\mu_{1}}$,

where $i=1,2,3,4$ correspond to the $\mathrm{L} 1, \mathrm{~L} 2, \mathrm{U} 1$ and $\mathrm{U} 2$ stages as shown in Fig. 27, respectively; $F_{\mathrm{dg}, i}$ is the draft gear force; $\Psi_{i}$ is the corresponding force coefficient; $F_{\mathrm{sm}}$ and $F_{\mathrm{sr}}$ are the main spring force and the release spring force, respectively; $\alpha, \beta$ and $\gamma$ are wedge shoe angles; $\mu_{1}, \mu_{2}$ and $\mu_{3}$ are the corresponding coefficients of friction.

The friction model can be expressed as

$\mu=h_{1}+h_{2} \exp \left(-h_{3} v_{\mathrm{r}}\right)$,

where $\mu$ is the coefficient of friction; $v_{\mathrm{r}}$ is the relative velocity of the two adjacent objects; $h_{1}, h_{2}$ and $h_{3}$ are parameters that need to be determined experimentally or empirically: $h_{1}$ represents the kinetic friction, the sum of $h_{1}$ and $h_{2}$ represents static friction, and $h_{3}$ is used to adjust the transition from static friction to kinetic friction. For further information refer to [36, 54].

In 2016 Cole et al. [41] published a single tuneable equation for single pack, balanced and floating plate draw gear systems. The equation can be used for pre-load and pre-compression cases [41] for each type of passenger draft gear. Equation (16) can be used for freight draft gears

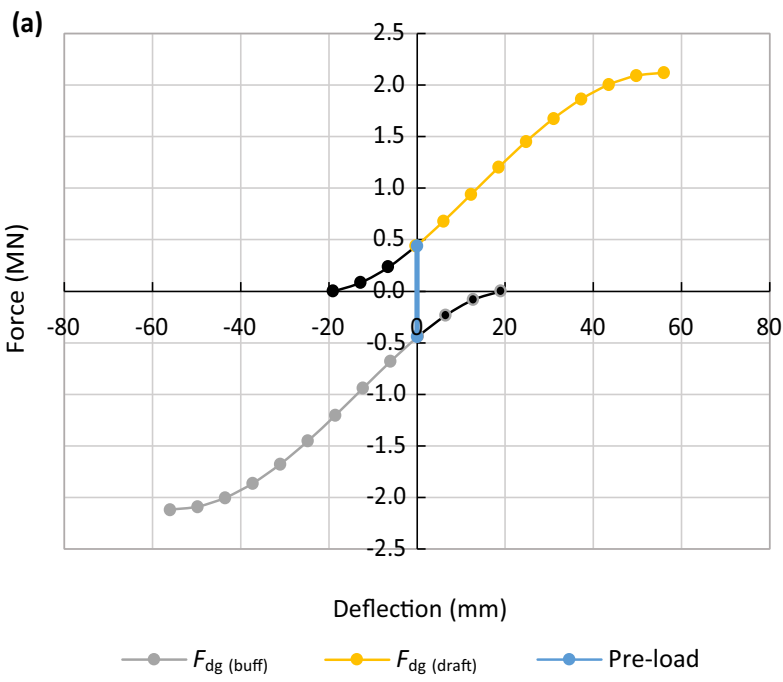

combined with the equations provided in Sect. 11.1-11.3 for each specific draft gear.

$$
\begin{aligned}
F_{\mathrm{dg}}(x, v)=F_{\mathrm{m}}+F_{\mathrm{d}}(x, v)= & 0.5 \sum_{i=1}^{6} a_{i-1} x^{i}+0.5 \sum_{i=1}^{6} b_{i-1} x^{i} \\
& +\left(x / x_{\max }\right)\left(F_{\mathrm{f}}(v)+C_{1} v+C_{3} v^{3}\right),
\end{aligned}
$$

where $F_{\mathrm{dg}}$ is the draft gear force, $F_{\mathrm{m}}$ is the mean of the sixth order polynomials that approximate the experimental data; $F_{\mathrm{d}}$ is the damping force component; $a$ and $b$ are coefficients for the sixth order polynomial that approximate loading and unloading of the experimental data; $x$ is the deflection of the draft gear, and $x_{\max }$ is the maximum expected deflection of the draft gear; $v$ is the working velocity of the draft gear; $F_{\mathrm{f}}(v)$ is a nonlinear friction damper (i.e. coulomb damping); and $C_{1}$ and $C_{3}$ are viscous and nonlinear viscous damping coefficients.

\subsection{Single pack draw gear system}

The single pack draw gear system is discussed in detail in Sect. 5.3. This section covers the modelling of the draw gear system.

In the pre-load case for the single pack draw gear system the following equation is used [41]:

Let $x=x+x_{\text {preload }}$, where $x_{\text {preload }}$ is the value that gives $F_{m}\left(x_{\text {preload }}\right)=F_{\text {preload }} ; x$ is then substituted into Eq. (16).

Figure 28 shows the pre-load case for loading the single pack draw gear in buff (compressive) and draft (tensile). Note that the single pack draft gear compresses under both buff and draft loading conditions (Fig. 28b). Pre-load can be accommodated by moving the curves to the left (Fig. 28a) which just reflects how preload is applied during

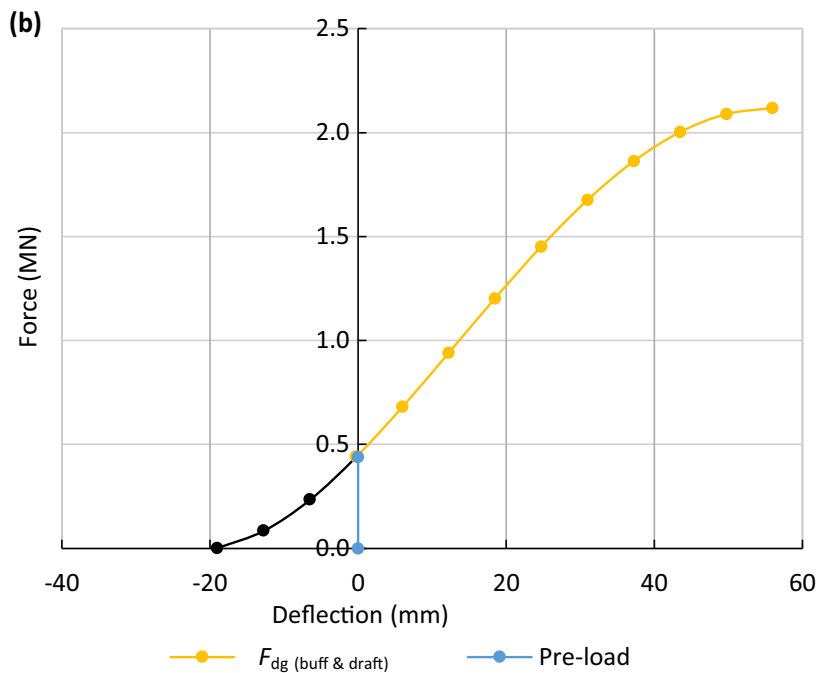

Fig. 28 Single pack draft gear pre-load case (only loading): a single pack draw gear; b polymer spring 

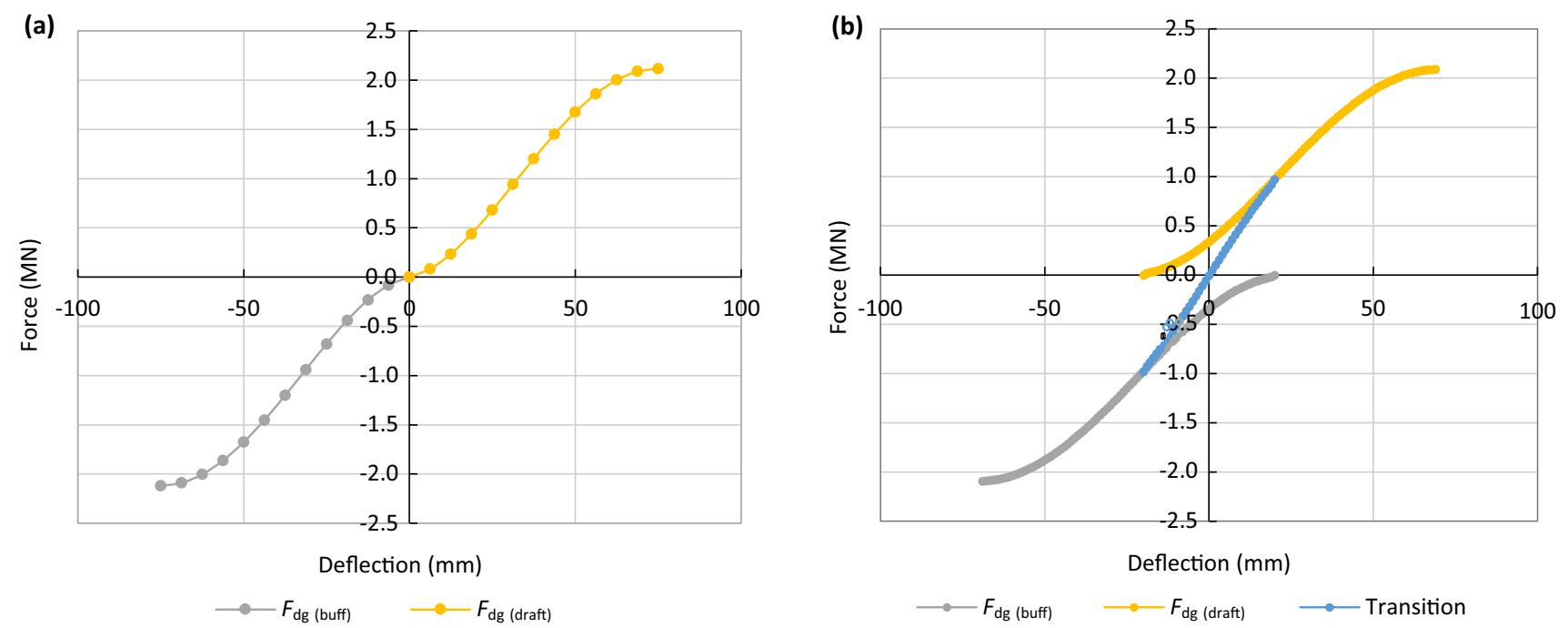

Fig. 29 Balanced draft gear (only loading): a no pre-compression case; b pre-compression case

assembly. As a single pack draw gear system is constrained by the pocket, a step preload force must be overcome before the draw gear system starts acting like a polymer spring. In Fig. 28 the black sections of the plot would be removed and only the positive section would be included. It was included in this graph to demonstrate the movement of the polymer curve.

\subsection{Balanced draw gear system}

Balanced draw gear systems consist of two polymer (or elastomer) springs on a pre-tensioned rod, ensuring that the polymer springs are in a pre-compressed state. The pretensioning is achieved by tightening the nut on the rod. These draw gear systems are typically used in passenger or light rail services. Balanced draw gear systems are covered in detail in Sect. 6 and shown in Fig. 19. Modelling of balanced draw gear systems can be achieved by combining the approaches of papers published by Cole et al. $[41,42,58]$ the formulas for balanced draw gear and floating plate draw gear systems can also be solved.

The force in the balanced draw gear system can be described below [41]. Solving the equation for the pre-load and pre-compression case can also be achieved.

In the pre-compression case [41] (utilising Eq. (11)), the zones of influence of the parallel stiffnesses must be first be defined. This means that the pre-compression in buff and draft must be determined by considering the deflection of the springs in buff and draft individually, $x_{\text {pre-compression(buff) }}$ and $x_{\text {pre-compression(draft) }}$. These deflections must be determined such that

$$
\begin{aligned}
& F_{\mathrm{dg}(\text { buff })}\left(x_{\text {pre-compression }(\text { buff })}\right)=F_{\mathrm{dg}(\text { buff })}\left(x_{\text {pre-compression }(\text { draft })}\right) \\
& =F_{\text {pre-compression }}
\end{aligned}
$$

where $F_{\mathrm{dg}(\mathrm{draft})}$ and $F_{\mathrm{dg}(\text { buff })}$ denote the $F_{\mathrm{dg}}$ (draft gear force) parameters of buff and draft, respectively, and $F_{\text {pre-compression }}$ denotes the pre-compression force.

There are then three cases of evaluation depending on the displacement range the draft gear is working in: $x \geq$ $\left|x_{\text {pre-compression(buff) }}\right|$ then $F_{\mathrm{dg}(\mathrm{draft})}\left(x+x_{\text {pre-compression(draft) }}\right)$, $x \leq-\left|x_{\text {pre-compression(draft) }}\right|$ then $F_{\text {dg(draft) }}\left(x-x_{\text {pre-compression(buff })}\right)$, $x>-\left|x_{\text {pre-compression(draft) }}\right|$ and $x<\left|x_{\text {pre-compression(buff) }}\right|$ then $F_{\text {combined }}=F_{\text {dg(draff })}\left(x+x_{\text {pre-compression(draft })}\right)+F_{\text {dg(buff })}(x-$ $\left.\left|x_{\text {pre-compression(buff) }}\right|\right)$, where $F_{\mathrm{dg}(\mathrm{draft})}$ and $F_{\mathrm{dg}(\text { buff })}$ are evaluated as per Eq. (16) and $F_{\text {combined }}$ is the special case where the buff and draft springs act as parallel stiffnesses.

Figure 29 shows the pre-compression case for loading for a balanced draw gear system. Pre-compression simultaneously loads both buff and draft polymer springs. This can be visualised as moving the $\mathrm{x}$ axis based on the amount of pre-compression. The blue line between the curves is the summation of the two and the shifting of the axis, noting that the system is stiffer where the two polymer springs work together. Figure 29 only shows the loading cases to demonstrate the difference between the no pre-compression and the pre-compression case. If the unloading case were shown, another two graphs are required. In Fig. 29b the overhanging sections would be removed showing the resulting deflection to force profile. 


\subsection{Floating plate draw gear systems}

Floating plate draw gear systems are also used in passenger and light rail services. Floating plate draw gear systems are discussed in detail in Sect. 7 and shown in Fig. 21. Floating plate draw gear systems are also referred to as twin pack draw gears. As a brief introduction, when loaded in tension the floating plate draw gear is the same as a balanced draw gear. When loaded in compression the configuration acts the same as a single polymer spring. This gives different behaviours in different directions.

The floating plate case [41] is handled by combining the above approaches, utilising the preload equations for buff or compression forces and pre-compression equations for the draft or tensile forces.

\section{Discussion}

Increased train lengths and payloads have been an objective of railways since the pioneer railway days. This is likely to continue as railways seek to increase efficiencies and maximise throughput on existing rail infrastructure. Advancements in connection systems have the potential to provide improved damping and coupling systems, resulting in increases in energy absorption. Improvements in the energy absorbed reduce forces, resulting in the potential for longer trains. There are currently two modern innovations, these being the double draft gear system and the long pocket polymer draw gear system which delivers improved energy absorption over current designs such as the polymer friction wedge draft gear.

For railway connection systems, two separate design development paths are necessary, namely for the coupler and for the draw gear. In North America, the primary driver for the development of the coupler has been personnel safety [2]. Earlier couplers such as the link and pin coupler were unsafe and constantly put railway workers in harm's way. Between 1877 and 1887, approximately 38\% of rail worker incidents involved coupling of the link and pin coupler [2]. In 1893 the Janney Coupler became standardised throughout the USA to reduce safety incidents of personnel [1, 2, 7]. Since 1902 the Janney Coupler has largely stayed unchanged.

As connection systems developed, there has also been a path of reducing slack. Earlier designs such as the buff and chain coupler and the link and pin coupler had high levels of slack action. The introduction of the Miller Hook and Platform and later the Janney Coupler reduced slack action between vehicles, refer to Table 2 . It has been shown that reduced slack action can reduce in train forces and hence minimise derailment risk [59].
The development path of the draft gears has generally been based mainly on crash performance. Earlier models such as the steel spring friction draft gears tend to have a sudden increase in force at the end of the drop hammer performance graph as shown in Table 12. The introduction of polymer springs combined with friction wedges provided an improved drop hammer performance graph and higher capacity as shown in Fig. 11, Tables 12 and 13.

In 1989 Duncan and Webb [60] observed that when trains are in-service, friction wedge draft gears can become locked causing the train to act as a continuous body. When draft gears are locked, the train has virtually no damping. In such cases low frequency longitudinal vibrations can occur and these will continue until the draft gears progressively release [60]. This behaviour was later confirmed by Cole et al. in 1999 [61] and observed recently on the mainline [40]. Even though this phenomenon was first observed more than 30 years ago, it is still present in train operations and is inherent in friction wedge draft gear design (refer to Table 5).

In 2016 the disconnect between the laboratory test data and field measurements was observed at rotary tippler operations [62]. In 2016, Kovalev et al. [62] stated that a reliable prediction of in-train forces cannot be achieved without accurate draft gear performance curves. Arguably, more comprehensive modelling of draft gear performance curves has been used with tippler simulations by Cole et al. $[21,63]$. Even though it is understood that the laboratory tests and field measured data produce different performance curves, the laboratory tests are used as part of the acceptance criteria for all countries [23, 30, 31]. As friction draft gears are the most widely used [6] for freight services and the acceptance standards $[23,30,31]$ are unlikely to change in the near future, this phenomenon is likely to continue.

The behaviour of draft gears becoming locked has been included for both normal train operations and shunting type impacts in the CRE researchers' simulator (CRE-LTS) [43] and has also been utilised by other external researchers [64]. Wu [43] states that draft gear designs that just comply with wagon impact and drop hammer tests may not necessarily produce designs that are optimised for mainline train operations. This observation can also be extended to the rotary tippler [40]. Therefore, the opportunity to use train simulation as a method of optimising the design of draft gears exists.

Train simulation could also be used as part of the acceptance criteria for draft gears. The earliest relevant document related to longitudinal train dynamics was in 1967 [65]. It was not until the 1980s that the development of software packages for longitudinal train simulation began as there was a lack of computing capability before this time [65]. Even though train simulators have been 
around since the 1980s, they still have not found a way into the acceptance criteria for draft gears.

\section{Conclusion}

Longer heavier trains remain as the primary production goal for many railways throughout the world due to the efficiencies and cost savings that it creates. Rolling stock connection systems are key to achieving longer heavier trains as they are the longitudinal suspension and connection system of the train. Advancements in rolling stock connection systems can not only allow longer and heavier trains but may also increase the safety and efficiency of existing trains. A good example of these opportunities is the extreme heavy haul environment operating in the iron ore industry in the Pilbara of Western Australia where trains are approximately $2.5 \mathrm{~km}$ long and weighing 30,000 tonnes. Increases in train payload can increase supply chain throughput with minimal capital outlay.

Based on the review material, it was found that modern freight rolling stock systems have adopted or are still progressively adopting the Janney type auto-coupler. From the 1800s draft gears have evolved from basic buff and chain couplers to modern polymer spring and friction wedge systems. The friction type draft gear is dominant throughout the world. Innovations in freight trains tend to be driven by the heavy haul train sector which require operations at higher in-train forces (i.e., approaching $2 \mathrm{MN}$ ).

A wide range of coupler systems are currently utilised, but the AAR coupler (Janney coupler) remains the most popular. Refined versions of the buff and chain coupling are, however, still in use in the EU, UK, South America and India. A further variation is the SA3 coupler (improved Wilson coupler) which is an auto-coupler used throughout the former Soviet Union. New connection systems such as the SA5 coupler are also in development by the European Union.

In 1896 friction draft gears were introduced into service which comprised steel spring nests combined with friction wedges. These designs have developed into the modern steel spring friction draft gears in-service today which typically have a maximum force rating of approximately 1.7 MN. Further development of these designs resulted in replacing the steel spring nest with a polymer spring. The introduction of polymer springs resulted in a heavier design with maximum force ratings of approximately $2.2 \mathrm{MN}$. Today, further developments are still underway. The modern innovations currently being developed introduce larger pocket sizes into the design, which is expected to further increase the energy absorbed such as the recently introduced double draft gear systems using pairs or combinations of standard friction type draft gears and new long polymer draw gear system introduced by Strato Inc. Other alternate systems exist, such as hydraulic draft gears which are limited to approximately $1.5 \mathrm{MN}$.

These recent long pocket innovations confirm that there are needs and opportunities to improve draft gear performance. Again, in heavy haul trains it has long been known that the draft gear acceptance tests (drop hammer, collision impact, etc.) do not give indications of performance during in-service longitudinal train behaviour which is quite different from the crash-impact behaviour. Design will, however, always have strong focus on product acceptance tests, so improvement in draft gear design will also depend on developing new test parameters and methods of quantifying key parameters of in-service longitudinal train behaviour.

Open Access This article is licensed under a Creative Commons Attribution 4.0 International License, which permits use, sharing, adaptation, distribution and reproduction in any medium or format, as long as you give appropriate credit to the original author(s) and the source, provide a link to the Creative Commons licence, and indicate if changes were made. The images or other third party material in this article are included in the article's Creative Commons licence, unless indicated otherwise in a credit line to the material. If material is not included in the article's Creative Commons licence and your intended use is not permitted by statutory regulation or exceeds the permitted use, you will need to obtain permission directly from the copyright holder. To view a copy of this licence, visit http://creativecommons. org/licenses/by/4.0/.

\section{References}

1. Wikipedia (2020) Railway coupling. Wikipedia. https://en. wikipedia.org/wiki/Railway_coupling

2. McDonald CW (1993) The federal railroad safety program. 100 years of safer railroads. Federal Railway Administration, Washington, DC

3. Agricola G (1950) De re metallica (trans: Hoover HC, Hoover LH). Translated from the First Latin Edition of 1556. Dover Publications, New York, NY

4. Waggonway Research Circle (2005) The wollaton wagonway of 1604. Island Publishing, Portland

5. Wikipedia (2021) List of horse-drawn railways. Wikipedia. https://en.wikipedia.org/wiki/List_of_horse-drawn_railways

6. Wu Q, Cole C, Luo S, Spiryagin M (2014) A review of dynamics modelling of friction draft gear. Veh Syst Dyn 52(6):733-758

7. Janney EH (1873) Improvement in car-couplings. United States Patent 138405

8. Rail Industry Safety and Standards Board (RISSB) (2018) AS 7524: coupler and draft gear. Australian standards, Canberra, Australia

9. AAR Mechanical Division (1986) AAR manual of standards and recommended practices, Chapter II. Section 2.1. Association of American Railroads, Washington, DC

10. Wikipedia (2020) Buffers and chain coupler. Wikipedia, https:// en.wikipedia.org/wiki/Buffers_and_chain_coupler

11. Miller (1866) Miller and hook platform. United States Patent US56594A 
12. Wikipedia (2021) Railway coupling by country. Wikipedia, https://en.wikipedia.org/wiki/Railway_coupling_by_country

13. Wikipedia (2021) SA3 coupler. Wikipedia, https://en.wikipedia. org/wiki/SA3_coupler

14. European Commission (2020) FR8RAIL: Development of functional requirements for sustainable and attractive European rail freight. https://cordis.europa.eu/project/id/730617. Accessed 30 June 2020

15. Funke U (2017) Development of functional requirements for sustainable and attractive european rail freight. D5.1 - state of the art on automatic couplers. FR8RAIL, Luxembourg, Germany

16. Shif2Rail (2020) Digitalization and automation of freight rail. https://projects.shift2rail.org/s2r_ip5_n.aspx?p=FR8RAIL\%20ii. Accessed 30 June 2020

17. Öngüner E, Henning A (2020) Digitalization and automation of freight rail. Deliverable D1.2 - automatic coupling, running gear and wagon design. FR8RAIL II, Horizon 2020 - european union funding for research and innvovation

18. Miner Enterprise Inc. (2020) Crown SG-M901G/Group K-Draft Gears. https://www.minerent.com/products/dg_CrownSG.php

19. Miner Enterprises Inc. (2013) Reconditioned draft gear guidelines. https://www.minerent.com/pdf/Recon_Draft_Gear_Poster. pdf

20. Sigra Technology Australia Pty Ltd (2020) Draft Gear Classification Guidelines (2020) http://www.sigrail.com/Draft

21. Cole C, Spiryagin M, Bosomworth C (2017) Examining longitudinal train dynamics in ore car tipplers. Veh Syst Dyn 55(4):534-551

22. Bills J, Entwistle R (2012) Improvements to train positioning velocity profiles. In: CORE 2012: global perspectives; conference on railway engineering, 10-12 September 2012, Brisbane, Australia. Engineers Australia, p 21

23. National Standards of the Russian Federation (2014) GOST 32913 - devices absorbing coupling and automatic couplers of railway rolling stock Technical requirements and acceptance rules (Reissue). Russian Federation, Moscow, Russia

24. Koturanov VA (2014) Substantiation of indicators characterizing the innovativeness of automatic coupler draft gear structures under conditions of shunting collisions. State University of Railways, Ministry of Railways of the Russian Federation (MIIT), Moscow, Russia

25. Crown SE ${ }^{\mathrm{TM}}$-M901E/Group J-Draft Gears- Miner Enterprises Inc. (2020) https://www.minerent.com/products/dg_CrownSE. php

26. Miner Enterprises Inc. (2016) TF- $880^{\mathrm{TM}}$-M901E / Group J-Draft Gears I Miner Enterprises, Inc. Miner Enterprises, Geneva, IL

27. Miner Enterprises Inc. (2017) SL-76 ${ }^{\mathrm{TM}}$-M901E । Miner Enterprises, Inc. Miner Enterprises, Geneva, IL

28. Miner Enterprises Inc. (2013) MINER TP--17 Draft Gear. Miner Enterprises, Geneva, IL

29. Indian Railways (2017) Upgraded high tensile centre buffer coupler. Research Designs and Standards Organisation, New Delhi

30. The Association of American Railroads (2012) Manual of standards and recommended practices - section B. Freight car draft components. The Association of American Railroads, Washington, DC

31. Ministry of Railways of the People's Republic of China (2006) TB/T 1961-2006 Draft gears for locomotives and cars. Beijing, China

32. National Standards of the Russian Federation (2012) GOST P 55185 - Parts and assembly units of coupling and auto coupling units of Railway rolling stock. Parts and assembly units of coupler and automatic coupler devices of railway rolling stock. Test methods. Russian Federation, Moscow, Russia
33. Spiryagin M, Cole C, Sun YQ, McClanachan M, Spiryagin V, McSweeney $T$ (2014) Design and simulation of rail vehicles. CRC Press, Boca Raton, FL

34. Association of American Railroads (2011) Manual of standards and recommended practices - section S-III. Coupler and yoke details. Association of American Railroads, Washington, DC

35. Association of American Railroads (2012) Manual of standards and recommended practices section B. Freight car draft components. Association of American Railroads, Washington, DC

36. Cole C, Spiryagin M, Wu Q, Sun YQ (2017) Modelling, simulation and applications of longitudinal train dynamics. Veh Syst Dyn 55(10):1498-1571

37. Sigra Technology Australia Pty Ltd (2020) Sigra rollingstockdraft gear. http://www.sigrail.com/draft_gear.html

38. Amsted Rail (2018) Endurance 325 friction draft gear. Chicago, IL

39. Bradken (2016) Heavy haul solutions - intermodal wagons. Bradken, Mayfield West, Australia

40. Birkin D, Constable T, Cole C, Bosomworth C (2014) Reduction of low frequency linear vibrations in long heavy haul consists. CORE 2014: Rail Transport For A Vital Economy:732

41. Cole C, Spiryagin M, Wu Q, Bosomworth C (2016) Modelling issues in passenger draft gear connections. In: The dynamics of vehicles on roads and tracks. In: Proceedings of the 24th symposium of the international association for vehicle system dynamics (IAVSD 2015), Graz, Austria, 17-21 August 2015. CRC Press, London

42. Cole C, Spiryagin M, Wu Q (2019) Modelling complex series combinations of draft gear springs. Paper presented at the IAVSD international symposium on dynamics of vehicles on roads and tracks, Gothenburg, Sweden, 12-16 August, 2019

43. Wu Q (2016) Optimisations of draft gear designs for heavy haul trains. Dissertation, Central Queensland University, Australia, Rockhampton

44. Wu Q, Yang X, Cole C, Luo S (2016) Modelling polymer draft gears. Veh Syst Dyn 54(9):1208-1225

45. Oleo International (2020) Oleo hydraulic draft gear. https://www. oleo.co.uk/products/rail/draft-gear

46. Zenert M (2003) Freight car draft arrangements. Wabtec Corporation, Wilmerding, PA

47. Wabtec Corporation (2020) Draft Gears - Mark 50. https://www. wabtec.com/products/1625/draft-gears-mark-50

48. Cardwell Westinghouse (2020) Cardwell Westinghouse products. https://www.wabtec.com/business-units/cardwell-westinghouse/ products

49. Escorts (2018) Transformation through engineering and innovation couplers. Esorts Railway Equipment Division, Haryana, India

50. Amsted Rail (2020) Draft sills and draft gear. https://www. amstedrail.com/products/freight-car-components/draft-sills-anddraft-gear/

51. Polach O, Berg M, Iwnicki S (2019) Simulation of railway vehicle dynamics. In: Handbook of Railway vehicle dynamics, 2nd Edn. CRC Press, Boca Raton, FL

52. Iler D (2018) End-of car energy management system for railcars. USA Patent US 10086852 B2

53. Ring M, Sunde J (2017) Cushioning apparatus for a railway car. USA Patent US 10308263 B1

54. Wu Q, Spiryagin M, Cole C (2015) Advanced dynamic modelling for friction draft gears. Veh Syst Dyn 53(4):475-492

55. Wu Q, Spiryagin M, Cole C et al (2017) International benchmarking of longitudinal train dynamics simulators: results. Veh Syst Dyn 56(3):343-365

56. Spiryagin M, Wu Q, Cole C (2017) International benchmarking of longitudinal train dynamics simulators: benchmarking questions. Veh Syst Dyn 55(4):450-463 
57. Cole C (2006) Handbook of Railway vehicle dynamics, S Iwnicki (ed). Taylor \& Francis, London, UK

58. Cole C, Spiryagin M, Wu Q, Bosomworth C (2017) Practical modelling and simulation of polymer draft gear connections. In: Paper presented at the first international conference on rail transportation, Chengdu, China

59. Wagner S (2004) Derailment risk assessment. Dissertation, Central Queensland University, Rockhampton, Australia

60. Duncan I, Webb P (1989) The longitudinal behaviour of heavy haul trains using remote locomotives. In: The fourth international heavy haul railway conference, Brisbane, Australia, 1989. Institution of Engineers, Australia, p 587

61. Cole CR (1999) Longitudinal train dynamics: characteristics, modelling, simulation and neural network prediction for Central
Queensland coal trains. PhD, Central Queensland University, Rockhampton, Australia

62. Kovalev R, Sakalo A, Yazykov V, Shamdani A, Bowey R, Wakeling C (2016) Simulation of longitudinal dynamics of a freight train operating through a car dumper. Veh Syst Dyn 54(6):707-722

63. Cole CR, Sun YQ, Spiryagin M (2015) Longitudinal train dynamics during indexer train unloading operations. International Heavy Haul Association, Virginia Beach, USA

64. Zhou P, Pudney P, Howlett P (2013) In-train forces from energyefficient driving strategies. In: 22nd national conference of the Australian society for operations research, Adelaide, Australia, 1-6 December, 2013

65. Wu Q, Spiryagin M, Cole C (2016) Longitudinal train dynamics: an overview. Veh Syst Dyn 54(12):1688-1714 